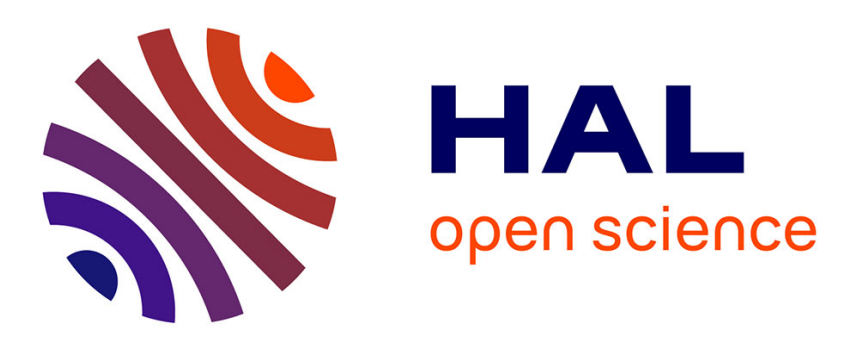

\title{
Biogenesis of d-amino acid containing peptides/proteins: where, when and how?
}

Céline Ollivaux, Daniel Soyez, Jean-Yves Toullec

\section{To cite this version:}

Céline Ollivaux, Daniel Soyez, Jean-Yves Toullec. Biogenesis of d-amino acid containing peptides/proteins: where, when and how?. Journal of Peptide Science, 2014, 20 (8), pp.595-612. 10.1002/psc.2637 . hal-01139947

\section{HAL Id: hal-01139947 https://hal.sorbonne-universite.fr/hal-01139947}

Submitted on 7 Apr 2015

HAL is a multi-disciplinary open access archive for the deposit and dissemination of scientific research documents, whether they are published or not. The documents may come from teaching and research institutions in France or abroad, or from public or private research centers.
L'archive ouverte pluridisciplinaire HAL, est destinée au dépôt et à la diffusion de documents scientifiques de niveau recherche, publiés ou non, émanant des établissements d'enseignement et de recherche français ou étrangers, des laboratoires publics ou privés. 
Céline Ollivaux ${ }^{\mathrm{a}, \mathrm{b}^{*}}$, Daniel Soyez ${ }^{\mathrm{d}, \mathrm{e}}$, Jean-Yves Toullec, ${ }^{\mathrm{f}, \mathrm{g}}$

\title{
Biogenesis of D-amino acid containing peptides/proteins: where, when and how?
}

Céline Ollivaux: ${ }^{a}$ Sorbonne Universités, UPMC Univ Paris 06, UMR 8227, Integrative Biology of Marine Models, Station Biologique de Roscoff, CS 90074, F-29688, Roscoff cedex, France. ${ }^{\mathrm{b}}$ CNRS, UMR 8227, Integrative Biology of Marine Models, Station Biologique de Roscoff, CS 90074, F-29688, Roscoff cedex, France

Daniel Soyez: 'Sorbonne Universités, UPMC Univ Paris 06, ER3, Biogenèse des signaux peptidiques, 7 Quai Saint Bernard, F-75251, Paris cedex 05, France. ${ }^{e}$ CNRS, ER3, Biogenèse des signaux peptidiques, 7 Quai Saint Bernard, F-75251, Paris cedex 05, France

Jean-Yves Toullec: 'Sorbonne Universités, UPMC Univ Paris 06, UMR 7144, Adaptation et Diversité en Milieu Marin, Station Biologique de Roscoff, CS 90074, F-29688, Roscoff cedex, France. ${ }^{9}$ CNRS,, UMR 7144, Adaptation et Diversité en Milieu Marin, Station Biologique de Roscoff, CS 90074, F-29688, Roscoff cedex, France

\author{
*Corresponding author: Céline Ollivaux \\ E-mail: ollivaux@sb-roscoff.fr \\ Phone: + 33298292553 \\ Fax: + 33298292310
}

\begin{abstract}
Peptides and proteins are chiral molecules with their structure determined by the composition and configuration of the amino acids constituting them. Natural amino acids (except glycine) display two chiral types (L- and D-enantiomers). For example, the presence of octopine, a derivative of L-arginine and D-alanine in octopus or peptidyl poly-D-glutamic acid in a bacterial cell wall was demonstrated in the 20ies and 30ies, respectively. Nevertheless, an old dogma in biology was that proteins (in a strict sense) are composed of amino acids in the L-configuration exclusively, until a D-alanyl residue was reported in a frog skin opioid peptide in the early 80ies and since, numerous D-amino acid containing peptides (DAACPs) have been discovered in multicellular organisms. Several hypotheses may be formulated to explain the origin of a Dresidue in the peptide/protein chain. It may result from different mechanisms such as incorporation of a D-amino acid, non-enzymatic racemisation associated with aging or diseases
\end{abstract}


and enzymatic post-translational modification. In the last case, the DAACPs are synthesised via a ribosome-dependent manner, and a normal codon for L-amino acid is present in the mRNA at the position where the D-residue is processed in the mature peptide by peptidyl aminoacyl L-D isomerisation, a peculiar and subtle posttranslational modification. In this review, the different pathways of biogenesis of DAACPs not only in bacteria but also in multicellular organisms are discussed, along with the description of the cellular specificity, the enzyme specificity and the substrate specificity of peptidyl aminoacyl L-D isomerisation.

Keywords: peptidyl isomerisation - racemisation - D-amino acid containing peptides - biogenesis - review

Abbreviations: cDNA, complementary DeoxyriboNucleic Acid; $\mathrm{CHH}$, Crustacean Hyperglycaemic Hormone; D-Phe ${ }_{3}-\mathrm{CHH}$, Crustacean Hyperglycaemic Hormone with a D-phenylalanine in position 3; DAACP, D-amino acid containing peptide; DLP, Defensin Like Peptide; EST Expressed Sequence Tag; IgG-Fc, Immunoglobulin G-fragment crystallisable région; MS, Mass Spectrometry; mRNA, Messenger ribonucleic acid. ORF, open reading frame; OvCNP, C-type natriuretic peptide (ovCNP-39) from platypus (Ornithorhynchus anatinus) venom; RACE, Rapid Amplification of cDNA Ends; RP-HPLC Reverse-Phase High Performance Liquid Chromatography; SG, sinus gland; VIH, Vitellogenesis Inhibiting Hormone; D-Trp 4 -VIH, Vitellogenesis Inhibiting Hormone with a Dtryptophane in position 4.

\section{Introduction}

A central dogma that has stood the test of time in biology was that proteins were composed exclusively of amino acids in the L-configuration and that unusual D- $\alpha$-amino-acids ( $D$ AAs) found in proteins (in a large sense) of several organisms were considered "special cases". For example, in the 20ies, the presence of octopine, a derivative of L-arginine and D-alanine was shown in muscle from octopus [1] and scallop [2] in the 30ies. The presence of a peptidyl poly-Dglutamic acid, a virulence factor in the bacterial cell envelope of the virulent Bacillus anthracis was also demonstrated in the 30ies [3]. Later, in the 40ies, a rapidly increasing number of microbial antibiotic peptides, containing D-AAs were discovered (review in [4]). At that time, the natural occurrence of D-AAs in proteins (in a large sense) was considered as a peculiarity of microorganisms; however, from the early 80ies, proteins (in the strict sense) containing a D-AA were found in animals, including man. For example, D-Asp has been found in several human proteins, such as dentin [5], aA-crystallin from the lens of patients with cataracts [6] and the $\beta$ amyloid peptide from the brain of Alzheimer's patients [7]. In these long-living proteins, the origin of peptidyl D-AAs may be explained by non-enzymatic racemisation and isomerisation associated with aging or disease [8]. However, independently from these phenomena, the first peptide 
containing de novo a D-AA was the dermorphin, an opioid peptide with a D-Ala ${ }^{2}$, characterised in skin secretion of the tree frog Phyllomedusa sauvagei [9]. Although at the time of publication, the scientific community was quite doubtful about this work, this was a real breakthrough in peptide studies. Since then, D-AA residues of different nature and at different positions have been found in bioactive peptides from the venom or nervous tissue of various species of molluscs, arachnids, crustaceans and vertebrates (platypus and frogs) (review in $[10,11]$ ). Only a single D-AA has been found in each peptide chain, close to one end, most frequently near the N-terminus. Moreover, a classical codon has always been found in the mRNA at the position where the Dresidue is present in the mature peptide $[12,13]$. The presence of a D-residue in the peptide chain may result from different mechanisms such as conversion of a free L-AA into its D-counterpart before its incorporation, or enzymatic posttranslational modification of an L-residue after polypeptide chain synthesis. At least, the change of a specific residue from the L- to the Dconfiguration results often in a modification of the biological activity of the peptide [14].

During the studies of these peptides, a number of different analytical methods have been used particularly chromatography because of theirs differential hydrophobicity and mass spectrometry because of their differential fragmentation [11,15-18]. However, detection of D-AAs in natural peptides has been, and remains a challenging task, as peptidyl aminoacyl L-D isomerisation does not induce any change in physicochemical properties of the molecule such as $\mathrm{pl}$, primary sequence or molecular mass. Therefore, a D-AA residue in a peptide chain is very difficult to detect and its characterization requires specific analytical approaches that will be described below.

In this report, along with the description of the diverse analytical techniques used for the detection and separation of DAACPs, the natural occurrence and the functional significance of these particular peptides will be reviewed followed by a description of the various pathways of the biogenesis of D-residues in polypeptide chains. It will focus on spatio-temporal characteristics, cellular and enzyme specificities and known mechanisms of the peptidyl aminoacyl L-D isomerisation.

\section{Incorporation of free D-amino acids before or during peptide elongation}

Many compounds, such as amino acids, can be processed via routes not involving mRNAs and ribosomes. These non-ribosomal peptides (NRPs) can contain D-AAs, which are incorporated by different biosynthetic pathways. In general, epimerisation of non-ribosomal peptides either occurs prior to amino acid activation, or during peptide elongation, neither of which is possible for the ribosomal peptides (RPs) based upon the current understanding of their biosynthesis [19]. In numerous bacteria, essential D-AAs have been notably found in the 
manufacture of cell walls. For example, D-alanine, D-aspartic and D-glutamic acids are commonly used for the synthesis of the peptidoglycan (i.e. a polysaccharide cross-linked with a short peptide) an essential constituent of the cell wall of Gram-positive and Gram-negative bacteria (Figure 1) [20,21] (review in [22]). The synthesis of the bacterial cell wall is believed to start with UDP-N-acetylmuramic acid, to which assorted free amino acids are added (L-Ala, D-Glu and meso-diaminopimelic acid) to generate UDP- $N$-acetylmuramyl-L-Ala-D-Glu-meso-diaminopimelate ([23] cited in [24]). Then, a D-Ala dipeptide is coupled to this intermediate of synthesis by UDP-Nacetylmuramoyl-tripeptide-D-Ala-D-Ala ligase. This dipeptide is produced by two enzymes: alanine racemase, and D-Ala-D-Ala ligase. The three-dimensional structure of the alanine racemase, the first one converting two common L-enantiomers of alanine to the D-counterparts has been elucidated (Figure 2). The D-Ala-D-Ala ligase generates a D-Ala dipeptide, which is then incorporated into the growing peptidoglycan peptide chain by UDP-N-acetylmuramoyl-tripeptideD-Ala-D-Ala ligase [24]. From the point of view of translational research, these products incorporated in the bacterial cell wall are interesting as they provide potential chemical markers to determine the presence of pathogens in animals, such as cows and pigs [25].

Other non-ribosomal peptides include antibiotics with a "simple" structure like the penicillins, which contain a D-valine moiety and a cycloserine derived from D-serine, but also more complex peptide antibiotics such as gramicidin, actinomycin, bacitracin, and polymyxin which are assembled in a stepwise fashion by the action of specific enzymes or enzyme complexes (the peptide synthetases) catalysing individual reactions. For example, the first step in the biosynthesis of penicillin $G$ is the condensation of two amino acids, L-amino-adipic acid which is an intermediate in the lysine biosynthetic pathway, and L-cysteine (Figure 3) [26]. Then, a L-valine is added to the two residues and epimerised to the D-form to generate the L-L-D-tripeptide, i.e. $\delta$ (L-Q-Aminoadipyl)-L-Cys-D-Val (ACV) by a catalytic multi-enzyme, $\delta$-(L- $\alpha$-aminoadipyl)-L-Cys-DVal synthetase that displays an epimerase domain in its C-terminal region [27]. The following steps in the biosynthesis of penicillin $G$ are the oxidative conversion of linear ACV into the bicyclic intermediate isopenicillin $\mathrm{N}$ by a specific enzyme, the isopenicillin $\mathrm{N}$ synthase and a transamidation by isopenicillin acyltransferase to produce penicillin $\mathrm{G}$ (review in $[28,29]$ ).

\section{Conversion of L- to D-amino acids in ribosomally synthesised antibiotics}

Unlike non-ribosomal peptides (NRPs), the natural ribosomal peptide products cannot (as far as is known) utilise amino acids beyond the canonical twenty proteinogenic amino acids, which, to a certain extent, limits their structural diversity. However, they can be extensively posttranslationally modified, and these modifications can lead to products with many features resembling those of the NRPs. In fact, many of the modifications commonly thought of as "nonribosomal" are also found in ribosomally synthesized peptides. Among these post- 
translational modifications, the conversion from the L- to the D-configuration without residue excision and replacement has been observed in another group of peptide antibiotics called lantibiotics (lanthionine-containing antibiotic peptides), produced by Gram-positive bacteria such as Streptococcus and Streptomyces to attack other Gram-positive bacteria, and as such, they are considered as members of the bacteriocin family. For instance, three examples of D-alanine containing peptides have been reported in these microbial peptides: lactocin $S$ which contains three D-alanines and is produced by Lactobacillus sakei [30], and Ltn- $\alpha$ and Ltn- $\beta$, the individual components of the two-peptide lantibiotic lacticin 3147 originally produced by Lactococcus lactis. Ltn- $\alpha$ and Ltn- $\beta$ possess one and two D-alanines, respectively (Figure 4) [31,32]. The mechanism by which these $D$-alanines are generated in lantibiotics is unique and involves the conversion of a ribosomally introduced L-serine to a D-alanine, thus changing both the side group and chirality of the original residue. When this phenomenon was first discovered in lactocin $S$, it was postulated that a conversion of L-serine to D-alanine occurred via a two-step process of a-carbon stereoinversion [30]. The first step involves the dehydration of serine to dehydroalanine (Dha), a common occurrence during lantibiotic biosynthesis, which, for the majority of lantibiotics, is catalysed by a lantibiotic synthetase. The second step, described for lacticin 3147, involved the enzymatically stereospecific hydrogenation of the Dha to form D-alanine. This is, to date, the only example whereby the enzyme(s) responsible for this modification, a lantibiotic dehydrogenase, has been identified. While lacticin 3147 and lactocin $S$ are the only ribosomally synthesized prokaryotic peptides known to possess the D-AAs, a number of homologues of the dehydrogenase have been identified in the genomes of Staphylococcus aureus, Pediococcus pentosaceus, and Nostoc punctiforme suggesting that others lantibiotics could contain D-AAs [33].

\section{Racemisation in ageing human proteins}

Over recent decades, D-AAs have been detected in various human tissues in the free form and as D-amino acyl residues in peptides and proteins. In particular, D-aspartyl residues have been detected in diverse proteins (elastin, myelin, crystallins) from various tissues of elderly individuals such as eye, brain, tooth and skin (for review [34]). D-Serine was also found in $\beta$ amyloid protein of patients with Alzheimer's disease [35] and in crystallin [36]. These findings are summarized in Table 1. Importantly, the proteins containing these D-AAs are derived from tissues that are metabolically inert. Thus, D-amino acyl residues arise due to racemisation of AAs in the proteins during the life span of the individual. Crystallin is a major structural protein of the lens, which is composed of $\alpha$-, $\beta$ - and $\gamma$-forms. $\alpha$-Crystallin is comprised of two types of subunits $\alpha A$ and $\alpha \mathrm{B}$. Contrary to $\beta$ - and $\gamma$-forms, $\alpha \mathrm{A}$ - and $\alpha \mathrm{B}$-crystallins, both display racemisation of aspartic acid and asparagine. In $\alpha A$-crystallin, the $D / L$ ratio is higher than 1.0 for Asp-151 and Asp-58; this 
means that the residues might undergo an inversion of configuration of L- to D-Asp and are not due to a simple racemisation [37]. A potential spontaneous mechanism by which Asp residues in proteins, especially $\alpha \mathrm{A}$-crystallin are isomerised to the D-form with age under particular physiological conditions, has been comprehensively described in [38,39]. Simultaneous formation of $D$ - and $\beta$-Asp residues (named $D-\beta$-Asp) from aspartyl residues in this protein could be explained as follows (Figure 5) [40]: (1) When the carbonyl group in the side chain of the Laspartyl residue is attacked by the nitrogen of the amino acid residue following the Asp residue, L-succinimide is formed by intramolecular cyclisation. (2) It is converted to D-succinimide through an intermediate [enol form] whose prochiral $\alpha$-carbon is in the plane of the ring. (3) Protonation of the intermediate may proceed from the upper or lower side of the plane in an ordinary peptide or protein. The area surrounding Asp-151 and Asp-58 residues in $\alpha A$-crystallin is thought to form a chiral environment that promotes formation of D-succinimide over L-succinimide. (4) D- and Lsuccinimide are hydrolyzed at either side of their two carbonyl groups, yielding both $\beta$ - and $\alpha$-Asp residues. As shown in Figure 5, D-Asp formation is also accompanied by isomerisation from the natural $\alpha$-Asp to the biologically rare $\beta$-Asp (isoaspartate). Thus, four isomers, L-Asp, L- $\beta$-Asp, DAsp and D- $\beta$-Asp, are simultaneously formed in the protein. The formation of these isomers at Asp-151 and Asp-58 of human $\alpha$ A-crystallin begins shortly after birth and thereafter they accumulate gradually during the aging process. As described above, the area surrounding the Asp may form a chiral environment, which allows the inversion of L- to D-configuration. Indeed, if the neighbouring amino acid of the Asp residue has a small side chain, such as alanine or serine, the formation of succinimide occurs easily because there is no steric hindrance [41]. In the primary amino acid sequence of $\alpha \mathrm{A}$-crystallin, Asp-151 and Asp-58 are followed by alanine and serine, respectively. Therefore, formation of succinimide is anticipated to occur readily along with inversion and this depends not only on the primary structure, but also on the higher order structure of the protein.

\section{Isomerisation of peptides in animals}

Independently of the age of proteins, it has long been assumed that in animals, natural residues in proteins existed exclusively in the L-form. But, contrary to all predictions, in 1981, a DAla residue was reported to be present at the second position in an opioid peptide, dermorphin, from the skin secretion of the tree frog Phyllomedusa sauvagei [9]. At the time of publication, the scientific community was quite doubtful about this work, but this subsequently proved to be a real breakthrough in peptide studies. Over the past three decades, more than 40 examples of DAACPs in animals have been reported. D-Amino acyl residues of different types have been found in bioactive peptides from the venom or nervous tissues of various species of molluscs, arachnids, crustaceans and vertebrates (platypus and frogs) (Table 2; reviews in [10,11,42-44]). 


\section{Where to find DAACPs? Occurrence in animals and functional significance}

To date, only a single D-amino acyl residue has been found in a given peptide sequence. The nature of the D-residue varies according to the peptides, although it has consistently been found near the extremities of the sequences at the second or third position, mostly near the $\mathrm{N}$ terminal end (Crustacean Hyperglycaemic Hormone, dermorphin...). A D-residue has been found near the C-terminus in few cases such as in a toxin isolated from the venom of the funnel web spider Agelenopsis aperta ( $\omega$-agatoxin 4B) [45,46] and in the R11 conotoxins (a, b and $c$ ) from the marine mollusc cone snail (Table 2). The situation is particular for short peptides like contryphans, since these hepta- or octapeptides isolated from the venom of the marine gasteropods Conus display a D-residue (tryptophan or leucine) at the central positions 3 or 4 $[47,48]($ Table 2).

From a biological point of view, different cases of figures can be observed. These are summarised in Table 3:

\section{1) Contrary to the D-isomer, the L-form is not naturally produced or has not been found}

(a) Isomerisation of one residue in the peptidic chain has been found to be crucial for proper bioactivity For example, the presence of $\mathrm{Ala}^{2}$ in the D-form is the sine qua non for the biological activity of the dermorphin from frog skin, binding exclusively to the $\mu$-opioid receptors $[9,49]$. This was supported by a number of experiments in which synthetic dermorphins containing an L-Ala ${ }^{2}$ (which has never been found in skin extracts) was consistently shown to be inactive, even in the presence of protease inhibitors [50]. This is also the case of the dermenkephalin with D-Met ${ }^{2}$ since L-Met ${ }^{2}$-dermenkephalin is virtually devoid of opioid activity $[51,52]$.

(b) However, in some cases, even if the L-form is not naturally produced or has not been found, the synthetic peptide with a L-residue displays slight activity. It is the case of the Lcounterparts of the cardio-excitatory tripeptide (Asn-D-Trp-Phe) purified from the heart of the gasteropod mollusc Aplysia kurodai [53] or of the pentapeptide (Phe-D-Asn-Glu-Phe-Val) fulicin extracted from ganglia of the pulmonate mollusc Achatina fulica that enhances the contraction of the penis retractor muscle [54]. They are at least 1000 and 3000 times more potent than the Lisomers, respectively.

(c) Another possibility is that the synthetic peptide with a L-residue and the natural D-form display the same activity. An interesting example is the FMRFamide-related decapeptide isolated from the anterior byssus retractor muscle of the bivalve mollusc, Mytilus edulis (MytilusFFRFamide with the sequence H-Ala-D-Leu-Ala-Gly-Asp-His-Phe-Phe-Arg-Phe-NH $\mathrm{N}_{2}$. Indeed, Fujisawa et al. [55] showed in 1992 that the synthetic peptides with an L-Leu ${ }^{2}$ and D-Ala ${ }^{1}$ have 
almost equipotent effects as the native peptide containing a D-Leu ${ }^{2}$. Their results suggest that the all-L C-terminal tetrapeptide fragment structure of Mytilus-FMRFamide is very important for excitatory action on muscle and that the $\mathrm{N}$-terminal hexapeptide portion containing the D-residue is not essential for activity. Contrary to most examples described above, the D-residue is probably not required for maintaining the correct molecular conformation of the peptide for activation of its receptors.

2) In other cases, both natural isomers were found in the tissue.

(a) In the African giant snail Achatina fulica, achatin I, a tetrapeptide (Gly-D-Phe-Ala-Asp) purified from the suboesophageal and cerebral ganglia was found as both isomers in tissue extracts [56]. The D-form may have a potent neuroexcitatory effect by inducing a stereospecific voltage-dependant inward current, due to $\mathrm{Na}+$ ions, on several heart regulatory cerebral neurons of the same snail. Likewise, a synthetic peptide with D-Ala (Gly-D-Phe-D-Ala-Asp), was also proved to be active, but at a level of less than $10^{-3}$ as potent compared to the natural Gly-D-PheAla-Asp isomer. In contrast, the peptide formed with only L-AAs, also present in the ganglia, is devoid of activity and to date no other function has been attributed.

(b) Like achatin, both natural $\omega$-agatoxin isomers were found in natural extracts, isolated from the web spider venom [57]. However, in this case, the L-form displays slight activity. Indeed, the D-isomer (IVB) was found to be a more potent blocker of the P-type voltage sensitive calcium channel in rats than its L-serine containing counterpart (IVA), which showed 80-90 fold less potent inhibition [46].

(c) In several Astacidae species (lobsters, crayfishes), Crustacean Hyperglycaemic Hormone $(\mathrm{CHH})$ is synthesised in the $\mathrm{X}$ organ-sinus gland complex. $\mathrm{CHH}$ is a 72-residues neuropeptide and was characterised as two isomers differing in the configuration of the Phe ${ }^{3}$, either as an L- or a D-form. Both isomers exhibit hormonal activities and regulate energy metabolism but the change in configuration results in modifications to the biological activity of the peptide [58,59]. Indeed, with regard to the physiological significance of this modification, it was established that $\mathrm{CHH}$ isomers display differences in the time course of the hyperglycaemic response following injection of the two peptides into crayfish. It was observed that the injection of $\mathrm{CHH}$ evoked a rapid hyperglycaemia with a maximal value reached after $2 \mathrm{~h}$, whereas the maximal response was attained only after 3-4 $\mathrm{h}$ when using $\mathrm{D}-\mathrm{Ph} \mathrm{e}^{3}-\mathrm{CHH}$. Moreover, this isoform increased potency in its hyperglycaemic effect (10 times more potent than the L-counterpart). Other additional functions were reported as it exhibits a potent inhibitory activity upon the molting gland during ecdysteroidogenesis $[59,60]$. More recently, its role in osmoregulation has also been demonstrated [61].

(d) The presence of both isomers with a difference in biological function has also been observed in the Vitellogenesis Inhibiting Hormone (VIH) a neurohormone found in the major 
neuroendocrine organ of decapod crustaceans, the $X$ organ-sinus gland complex located in eyestalk. The $\mathrm{D}$-form has only been characterised in a few macrouran crustaceans, particularly in lobster [62,63]. It is synthesised with either an L- or a D-tryptophanyl residue (VIH and D-Trp ${ }^{4}-\mathrm{VIH}$, respectively) in three Astacidae species (American and European lobster, Norway lobster) and acts on the reproduction of the lobster Homarus americanus. When American lobster VIHs were tested in a heterologous in vivo assay, only the all-L isomer VIHs displayed significant inhibitory activity with respect to repressing oocyte growth that had been induced by eyestalk removal in grass shrimps [64]. To date, contrary to all the cases described above, no function has been assigned to the counterpart D-Trp ${ }^{4}-\mathrm{VIH}$.

(e) A peptide with a D-amino acid residue, C-type natriuretic peptide (OvCNPb with a D$\mathrm{Leu}^{2}$ ) has also been described in the venom of a mammal, the platypus (Ornithorhyncus anatinus). But the functional significance of the D-amino acid in this peptide is unclear at present. Indeed, experiments performed by de Plater and coworkers [65] did not reveal any difference in activity between the two isomers (OvCNPb and OvCNPa its L-counterpart); they display the same potency in elevating cGMP levels, and producing vasodilatation in cultured vascular smooth muscle. Moreover, OvCNP also causes oedema and mast cell histamine release, and may have other biological activities that are yet to be discovered. A more comprehensive pharmacological study is therefore required in order to compare the spectrum of activities of the two isoforms. The platypus venom gland also produces Defensin Like Peptides (DLP), whose structure resembles those of the mammalian anti-microbial $\beta$-defensin. They are present in both configurations (DLP4 and DLP2 with a D-Met ${ }^{2}$ ) and their tertiary structures are very similar [66]. The incorporation of the D-AA has minimal effect on the overall structure in solution and to date, the role of both natural isomers in platypus is unknown.

When differences in biological actions and functions are observed between the L- and Dforms, several hypotheses can be proposed to explain this phenomenon. (i) It may be because naturally existing DAACPs, rather than their natural or synthetic L-form counterparts, interact with the endogenous receptors to cause the required physiological responses [67]. For a particular function, the receptor can be specific of the ligand containing a D-residue, whether the L-isomer is present or not. (ii) It is also thought that the modified structure of DAACPs makes it more difficult for the peptides to be degraded by endogenous aminopeptidases, thus increasing their stability [58]. Bansal et al. [68] proposed that this "stability bias" is exacerbated by the rate of isomerisation of the D-form of the substrate peptide being slower, than the L-isomer. Hence, in HPLC analysis, the greater abundance of the D-form of the substrate pairs is not only because of the equilibrium of the isomerisation reaction being biased toward the D-isomer, but the all Lpeptide is more likely to be hydrolyzed by aminopeptidases in the medium, depleting it further than would otherwise be the case. The medium in which the peptides are immersed may be the 
internal medium of the animal itself as in case of the hormones $\mathrm{CHH}$ and $\mathrm{VIH}$ or the tissues of the victims injected with toxins, such as the spider agatoxin, mollusc conotoxins and the platypus DLP; the D-form would be more stable in the victim thus prolonging its effects such as pain. In this biochemical context, a recent concept of mechanism of metabolite separation named "chiral compartmentation" in metabolism, that emerged from the stereo-specificity of enzymes for theirs substrate(s) has been proposed from these observations [69]. In the case of platypus DLP, chiral compartmentation applies after envenomation: the D-containing peptide DLP4 is resistant to aminopeptidase, which is L-specific. Hence the venom component will reside in the tissue of the victim for longer that would otherwise have been the case because the DAACP is "operationally compartmentalized" from L-stereospecific aminopeptidase(s). Thus, the authors speculated that a selective advantage exists for the platypus to have venom components that persist for longer in the envenomated victim. However, the hypothesis of an increased stability of the D-isomer regarding the putative L-stereospecific aminopeptidase(s) was refuted for $\mathrm{CHH}$ since a recent publication [70] has demonstrated that both isoforms of $\mathrm{CHH}$ were cleared at a similar rate from the haemolymph of the Crayfish Astacus leptodactylus. Rather, the difference in biological activity, for $\mathrm{CHHs}$ at least, may be, as proposed above for the hypothesis (i), attributed to binding to different target tissues or, in the same tissue, onto different receptors.

\section{At which step of peptide biogenesis does isomerisation occur? Timing of the reaction}

Since the discovery of the first DAACP, dermorphin in 1981, the origin of the D-AAs in animal peptides has been under debate. The two hypotheses are that, either these peptides are assembled in a stepwise fashion with the incorporation of a D-residue in this process, or the chemical modification of an L- into a D-residue takes place as described above for the bacterial antibiotics. The second hypothesis is that the peptides are biosynthesized by a classical ribosome-associated mechanism. In the latter, the question arises whether the D-residue is incorporated directly into the peptide sequence, or is formed, after peptide synthesis, by a posttranslational reaction. Moreover, in this second case, does this modification occur before or after cleavage of the precursor?

Using molecular cloning techniques, it has been demonstrated that numerous DAACPs are derived from larger precursor molecules [71]. The classical isolation procedure was PCR amplification of either cDNA libraries or mRNAs prepared from tissues, using degenerate sense and antisense primers from the sequence encoding a similar peptide of another animal species. The normal codon for an L-AA was always described in the position where a D-residue was present in the protein end product. Thus, it is now generally agreed that peptides containing a DAA are derived from precursor polypeptides comprising only L-residues [72].

The next question was to identify if isomerisation is an early reaction that occurs in the 
intact precursor polypeptide (as e.g. the hydroxylation of prolines [73]), or a reaction that takes place after partial or complete processing late in the secretory pathway.

Evidence presented by Mor et al. [74] suggested that the D-residue is already present in the precursor of frog dermorphin, a heptapeptide with a D-Ala ${ }^{2}$. High molecular weight material was purified by chromatography from extracts of $P$. sauvagei skin and digested with trypsin and carboxypeptidase B. As expected from the precursor sequence, this digestion yielded the decapeptide dermorphin-Gly-Glu-Ala. Using specific antibodies, it could be demonstrated that the isolated fragment already had a D-alanyl residue in the second position. This suggested that the conversion of L- to D-Ala takes place in the intact precursor. However, these results do not exclude the presence of pre-pro-dermorphin with a L-Ala ${ }^{2}$ that is produced ribosomally. In contrast, Auvynet et al. [75] did not find a D-residue in pre-pro-deltorphin I, another precursor produced also in the frog skin. Indeed, by using specific antibodies, they showed that deltorphin I (also a heptapeptide with a D-Ala ${ }^{2}$ ), and dermaseptin B2 are stored together in secretion granules in the serous glands. Although the pre-pro-dermaseptin B2 and pre-pro-deltorphin I have a common pre-pro-sequence containing signal peptide and acid peptide, and enter identical subcellular compartments where they are processed to produce the mature products (deltorphin I, L-Ala ${ }^{2}$-deltorphin I and dermaseptin B), only deltorphin I is transformed by isomerisation. These three peptides are all stored together in secretion granules, which accumulate in the cytoplasm of the serous glands. The authors concluded that the isomerisation of deltorphin I occurs in the secretory granules as a late post-translational event. Nevertheless, to our mind, the question whether the D-residue is already present in the precursor or not, remains unanswered, since the presence of the all-L-preprodeltorphin I does not exclude the existence of a putative preprodeltorphin I with a D-Ala ${ }^{2}$.

Study of the dynamics of precursor maturation of $\mathrm{CHH}$ isomers $\left(\mathrm{CHH}\right.$ and $\left.\mathrm{D}-\mathrm{Phe}{ }^{3}-\mathrm{CHH}\right)$ allowed the dissection of the spatio-temporal characteristics of the different steps of isomerisation $[76,77]$. To our knowledge, this is the only model for which the different steps of the posttranslational processing of the precursor (cleavage, C-amidation, isomerisation and $\mathrm{N}$ pyroglutamination) have been comprehensively characterised and the kinetics of isomer maturation estimated in the different parts of the neuroendocrine complex. It has been clearly highlighted using the complementary techniques of radioactive labelling, enzymatic cleavage and immunochemistry with specific antibodies, that the isomerisation of $\mathrm{CHH}$ occurs after the propeptide cleavage and before $\mathrm{N}$-terminal cyclisation (in a step-wise fashion to avoid steric hindrance). Moreover, results indicate that newly synthesised $\mathrm{CHHs}$ are preferentially released, for both isomers. A robust demonstration of the absence of proCHH containing a D-Phe ${ }^{3}$ has been performed by purification of the only HPLC peak corresponding to the proCHH, and enzymatic cleavage of the material from this peak followed by ELISA with specific antibodies 
raised against $\mathrm{CHH}$ and $\mathrm{D}-\mathrm{Ph}{ }^{3}-\mathrm{CHH}$. No immunoreactivity for the $\mathrm{D}$-form was detected by this method.

In conclusion, even if the paucity of information on the isomerisation stage in DAACPs of species, except crustaceans and frogs, prevents any overall generalisations, it is now largely accepted that the DAACP precursor is an all-L sequence. Alternative possibilities, such as the incorporation of D-AAs into the primary product of translation or excision of certain L-AAs and reinsertion of the corresponding D-isomer are unlikely.

\section{Is there a cellular specificity of isomerisation? Cellular and subcellular distribution of isomers}

As described above, over the past 30 years, DAACPs have been regularly discovered in the various tissues of different animal species but rarely described at the cellular level. The frog skin serous glands which are syncytial, produce the D-isomer of deltorphin I (a heptapeptide with a D-Ala ${ }^{2}$, and isomerisation occurs in all the glands [75]. Staining the serous glands with antideltorphin I or anti-L-Ala ${ }^{2}$-deltorphin I antibodies produced similar overall patterns of fluorescence in all glands, with dense labelling confined to the secretory granules. There was no noticeable difference in the relative intensities and granular localisations of the specific labelling with the anti-deltorphin I and anti-L-Ala ${ }^{2}$-deltorphin I antibodies, although several serous glands were examined. The absence of glands labelled exclusively by the anti-deltorphin I or the anti-L-Ala ${ }^{2}$ deltorphin I antibodies suggested that there was no cellular or glandular specificity as the serous glands were producing mixtures of both deltorphin isoforms.

The situation is very different in the X-organ sinus gland (XO-SG) model of crustaceans because D-amino acid containing neurohormones are restricted to discrete, well-characterised neuroendocrine cells located in an easily accessible organ. So, cellular studies in crustaceans are more developed than in other animal models, in which the investigations have been mainly dealing with peptide characterisation and mode of action. Thus, the crustacean XO-SG complex enables the study of the precise cellular and sub-cellular localisations of the isomerisation process. As described earlier, the study of the dynamics of precursor maturation of $\mathrm{CHH}$ isomers using the complementary techniques of pulse-chase incubations followed by HPLC/ELISA/MS allowed the dissection of the spatio-temporal characteristics of isomerisation [77]. The conclusion that this post-translational reaction occurs preferentially in the soma of neuroendocrine cells was confirmed by immunofluorescent labelling using specific antibodies against $\mathrm{CHH}$ and $\mathrm{D}-\mathrm{Ph} \mathrm{P}^{3}-\mathrm{CHH}$ followed by analyses using confocal microscopy of the XO-SG complex [76]. In this study, an investigation of the structure of the $\mathrm{CHH}$-producing system was undertaken to elucidate what types of neurosecretory cells were involved in the production of the $\mathrm{CHH}$ isomers. Two distinct $\mathrm{CHH}$ cell types were observed, either labelled only by the antibody specific for the L-form (called L-cells) or 
labelled by antisera recognising both L- or D-isomers, (called D-cells; Figure 6 A, B, C). The number of the different $\mathrm{CHH}$ cells per organ was also constant in the studied species, the crayfish Orconectes limosus, with a total of $8 \mathrm{D}$-cells within a total of over $30 \mathrm{CHH}$ cells, as suggested in an earlier immunohistochemical study [78] (Figure 6A) and in the lobster Homarus americanus ([62,63]; Figure 6C). Soyez et al. [76] have observed that, in the D-cells producing a mixture of both isoforms, secretory granules identified with different antibody labels were not evenly distributed in the cytoplasm (Figure 6B). The clusters of L-labelled granules were generally in the perinuclear region whereas the peripheral part of the cytoplasm was enriched with mixed L- and Dlabelled or only D-labelled clusters. A major observation was that in every case, L-labelled fluorescence was no longer detectable as the granules entered the axon of these cells, suggesting that the majority of $\mathrm{CHH}$ was already isomerised when the granules left the soma (Figure 6B). Nevertheless, the greater sensitivity of immunogold labelling showed, at the ultrastructural level, that L-immunoreactivity in the axons of D-cells still appeared to be present but in very minute amounts [79]. To our knowledge, this is the only model for which a cellular specificity of this posttranslational reaction has been clearly shown. It is almost certainly due to differential expression of the putative isomerase(s) in the two cell types.

In addition to the example of $\mathrm{CHH}, \mathrm{VIH}$ and D-Trp ${ }^{4}-\mathrm{VIH}$ are two isomers produced by the same organ, the XO-SG complex but present in distinct cellular locations (Figure 6D) [62]. On the contrary, the use of specific antibodies against D-Trp ${ }^{4}-\mathrm{VIH}$ and D-Phe ${ }^{3}-\mathrm{CHH}$ showed that the Dforms of the two neuropeptides are not only produced in the same cells but, more importantly, are also co-packaged within the same secretory vesicules (Figure 6E). Consequently, with regard to these two hormones, five cell types in the XO-SG complex of lobster could be distinguished: VIH cells, $\mathrm{CHH}$ cells, D-Trp ${ }^{4}-\mathrm{VIH}$ cells, D-Phe ${ }^{3}-\mathrm{CHH}$ cells and cells producing both D-Trp ${ }^{4}-\mathrm{VIH}$ and D$\mathrm{Phe}^{3}-\mathrm{CHH}$ (Figure 7). A sixth cell type, producing a mixture of L-epimers of $\mathrm{CHH}$ and $\mathrm{VIH}$ has been postulated, but, a colocalisation of $\mathrm{VIH}$ and $\mathrm{CHH}$ has never been observed by confocal or electron microscopy techniques. Similarly, no axon terminal exhibited simultaneous labelling for $\mathrm{CHH}$ and D-Trp ${ }^{4}-\mathrm{VIH}$ or $\mathrm{VIH}$ and D-Phe ${ }^{3}-\mathrm{CHH}$.

NDWFamide (named NDWFa with the sequence H-Asn-D-Trp-PheNH $\mathrm{N}_{2}$ ), a D-tryptophancontaining cardioexcitatory neuropeptide in gastropod molluscs, such as Aplysia kurodai and Lymanea stagnalis has also been studied at the cellular level [72]. To determine the cellular distribution of this peptide and its transcript (NWF mRNA), abdominal ganglia of Aplysia kurodai were subjected to immunohistochemistry (IHC) by sequential double staining with a specific antibody (anti-NDWFa) and by in situ hybridisation (ISH) with specific DIG labelled oligo-DNA probes. The results revealed that neurons positively stained with ISH were also positive with IHC, suggesting that the precursor proteins and mature NDWFa peptides co-exist in the same neurons. However, this is not always the case and there were some ISH positive neurons, which did not 
show any fluorescence signals by IHC and in contrast some IHC immunopositive neurons that did not show staining positive to ISH probes. Several hypotheses have been formulated to explain this result. For example, in neurons positive with IHC but not with $\mathrm{ISH}$, it may be that plenty of NDWFa peptides are stored, but de novo peptide synthesis is blocked at the transcriptional level. Or it may be that another, not yet cloned, transcript of an NDWFa gene, not recognised by specific oligoDNA probes, is used for the synthesis of NDWFa in the neurons. Further investigations are required to understand the difference in distributions between the transcript and the mature peptide [72]. In this framework, to our mind, it would be judicious to use also an antibody against the L-isomer to investigate the cellular specificity of both isomers in the perinuclear regions and in the axons, like for the $\mathrm{CHH}$ cells, described above.

\section{Is there an enzyme specificity for each residue converted from the $L-$ to the D-form? Isomerase diversity}

All the isomerases studied to date act on intact polypeptides rather than on free AAs and require specific flanking residues to operate efficiently. Therefore, in a strict sense, the enzyme is not a racemase because it catalyses the interchange of diastereoisomers, not of enantiomers. By analogy to peptidyl prolyl cis-trans isomerase, the enzyme could thus be called a peptidyl aminoacyl L-D isomerase [44] or peptide epimerase [45].

The first enzyme catalysing isomerisation was isolated from the venom of the funnel web spider Agalychnis aperta [46]. This enzyme was found to interconvert two $\omega$-agatoxin IV, peptide toxins with 48 AAs (IVC and IVB), that differ only by the stereochemistry at serine 46 (L-Ser ${ }^{46}$ and $D-S^{46}{ }^{46}$, respectively), as described above. The complete primary structure of the isomerase was established by sequence analyses of the polypeptide chain, assignments of disulfide bridges, carbohydrate analyses, and mass spectrometry of sugar chains. The enzyme was found to be a $29 \mathrm{kDa}$ polypeptide with an 18-residue light chain and a 243-residue heavy chain interlinked by a single disulfide bond [80]. The heavy chain contained three intramolecular disulfide bridges and one $\mathrm{N}$-linked oligosaccharide chain with a single trimannosyl core structure [81]. Surprisingly, the heavy chain bears remarkable sequence identity to serine proteases such as thrombin and kallikrein (26\% and 35\%, respectively), particularly in the region of the conserved catalytic triad. Indeed, these hydrolytic enzymes operate via a catalytic triad, which act as proton acceptors and donors for the residue that will be isomerised in the peptide [82]. However, the residues in this active site of the isomerase have not yet been identified [10] and the gene and the RNA releasing the enzyme are not described, to date.

The first work by Torres et al. [66] on the detection of a peptide isomerase in a mammal, i.e. platypus, showed that an Ornithorhyncus venom gland extract had enzymatic activity that converted DLP4 to DLP2 (with a D-Met ${ }^{2}$ ). In 2006, Torres et al. [83] purified the isomerase by size exclusion chromatography followed by SDS-PAGE electrophoresis. Its molecular weight is +/- 
50-60 kDa and the authors noticed that the platypus isomerase showed similarity in its active site with some amino-peptidases since they both acted on or near the N-terminus and were both inhibited by the peptidase inhibitor amastatin. In another paper [84], isolation of the isomerase was carried out by combined ion-exchange chromatography and reverse-phase high performance liquid chromatography (RP-HPLC) providing a much better molecular separation because both the charge and hydrophobicity properties of proteins were utilized. This enzyme, that was only present in very small quantities in an extract of the venom gland, was thermally stable up to $55{ }^{\circ} \mathrm{C}$, indicating a relatively robust structural fold and it was found by anionexchange chromatography to be acidic [84]. The authors have also investigated other chromatographic methods such as hydroxylapatite and hydrophobic interaction columns but their separation performance did not give better results. The limited amount of available platypus gland extract and the extent of isomerase activity loss after each chromatographic step restrict more detailed studies of this system. As these techniques cannot be used to further separate and isolate the isomerase, the authors are currently sequencing candidate bands isolated from active fractions on SDS-PAGE gels and are also constructing a cDNA library from the platypus venom gland. This should allow the expression of putative isomerase gene(s) and testing of their enzymatic activities. Recent searches for peptide isomerase activity in other mammals has also shown that echidna venom (another monotreme [85]) and mouse heart contain a putative isomerase that has the same substrate specificity as platypus venom [86]. More surprisingly, a weak isomerase activity has also been reported for the first time in a plant (in papaya extracts). Indeed, the synthetic peptides corresponding to the N-terminus of DLP4 with a L-Met ${ }^{2}$ and DLP2 with a D-Met ${ }^{2}$, both produced by and originally identified in the Ornithorhyncus venom gland as described above, were found to be substrates of the papaya extract [87]. The phylogenetic distance between these two organisms (platypus and papaya) suggests that every living organism may have some peptide isomerase activity.

It was tempting to speculate that the isomerase from frog skin is homologous to that of platypus venom [42] since they both act on the second amino acid residue of peptides ( Met $_{2}$ ). Indeed, as described above, opiates (dermorphin with a D-Met ${ }^{2}$ and deltorphin containing a D$\mathrm{Ala}^{2}$ ), and antibacterial and haemolytic peptides like bombinins bearing a D-allo-lleu ${ }^{2}$ have been identified since 1981 in skin secretions of different species of amphibians. Nonetheless, it was only in 2005 that Jilek and co-workers [42] discovered a frog isomerase with an apparent molecular mass of $52 \mathrm{kDa}$ that converted the L-AA at position 2 of its substrate to the D-form. The enzyme was purified from the skin secretions of Bombina variegata and the $\mathrm{N}$-terminal sequence of the protein along with some of its cyanogen bromide fragments were determined by automated Edman degradation. Oligonucleotides deduced from these sequences were used for PCR experiments with total mRNA isolated from Bombina skin. This amplification yielded a cDNA 
fragment representing most of the first half of the isomerase. Northern blot analyses demonstrated that a large mRNA containing 8000 nucleotides encodes the enzyme. All attempts to amplify the rest of the isomerase with 5'- and 3'-RACE failed. In a different approach, Jilek and co-workers in 2005 [42] screened a genomic library prepared from the related species $B$. orientalis [88]. With specific primers designed from the previous sequence they isolated two clones containing the sequence of an exon with an ORF for 409 AAs, starting with residue 4 of the mature isomerase and part of an intron. The first 3 AAs of the enzyme and a pro-sequence or spacer sequence are encoded by a separate small exon. These two genomic fragments were assembled to produce a $B$. orientalis cDNA, which was translated into a polypeptide comprising 412 AAs. This cDNA coded for a protein with a deduced mass of $45 \mathrm{kDa}$. The cDNA and genomic fragments containing the genetic information for this protein did not code for a signal peptide and its ORF did not end with a stop codon. Starting with the sequence of the $B$. orientalis isomerase, they screened a cDNA library from skin of $B$. variegata by using PCR and suitable primers. Five different cDNAs, termed va to ve, were amplified and were sequenced fully or in part. All of these cDNAs coded for proteins that were $90 \%$ identical to the $B$. orientalis isomerase [42]. These homologous proteins are linked by spacer segments in the following order: -va-(33)vb- and -vc-(10)-vd-(48)-ve- (numbers in parentheses indicate the length of the spacers). The spacer sequences are relatively rich in proline and charged AAs. Individual isomerase domains are apparently excised from this polyprotein by unknown proteases. A search in the data bases for polypeptides related to the Bombina isomerase originally yielded only one major match, namely, the $\mathrm{N}$-terminal $\mathrm{H}$-domain of the human lgG-Fc binding protein [89] and not the platypus isomerase as it was expected. This domain comprises 450 AAs and has no known function. Subsequently, ESTs coding for fragments of related proteins from $X$. laevis and chicken were deposited in the data banks. Finally, in the genome of the fugu fish, three genes potentially coding for homologous proteins were characterised (FuguGenscan_26525, FuguGenscan_28866, and FuguGenscan_28655). The authors [42] have also shown that the change of chirality of L-lle to D-allo-lle at position 2 of a model heptapeptide with the $\mathrm{N}$-terminal sequence of bombinin $\mathrm{H}$ proceeds in both directions via the removal of a proton from the $\alpha$ carbon and a concomitant addition from the opposite side in an acid-base type of catalysis. As described above, such a mechanism has also been proposed for the isomerases from spider and platypus venoms.

To conclude, it seems surprising that structurally unrelated enzymes identified in spider, platypus and frogs can catalyse an identical reaction, the L- to D-isomerisation of AAs in processed peptides. Indeed, as described above, the spider isomerase has significant amino acyl residue sequence similarity with serine proteases, while the frog isomerase has some similarity to the $\mathrm{N}$-terminal $\mathrm{H}$-domain of human IgG-Fc binding protein. However, one must bear in mind that 
the AAs subject to the isomerisation reside at very different positions in the substrates of spider (position n-2 near the C-terminal end) and frog/platypus (position 2 near the N-terminal end) and are of different nature (Ser for spider, lle for frog and Met for platypus). Moreover, there would be no cross specificity since the frog enzyme does not act upon the heptapeptide corresponding to the N-terminus of platypus OvCNPa [42]. Conversely, platypus peptide isomerase does not convert the tripeptide corresponding to the $\mathrm{N}$-terminus of bombinin $\mathrm{H}$ of the frog secretion. Consequently, it can be thought that the enzymes have different active site configurations. This would be consistent with the information obtained on the different fold structures produced from preliminary chromatographic isolation procedures [90]. To date, it seems unconceivable to postulate that the isomerases described above belong to the same family and, as no consensus for sequences of the three enzymes has been found except for a pair of histidines, it would be amazing if they process peptides by the same reaction mechanism.

\section{How does isomerisation occur? Mechanistic pathway}

Although this clearly depends on the animal model and the peptide involved, one question that arises is whether this particular post-translational reaction is a racemisation yielding a mixture of L- and D-compounds or a quantitative (even complete) inversion of the chirality of the $\alpha$-carbon with the formation of the D-isomer as either exclusively or as a major proportion of the end product. This is difficult to determine exactly as there is a bias if the initial reaction takes place at the same time as the degradation by exo- or endo-peptidases of the L-isomers, which would then decrease in relative abundance. Moreover, the possibility that the presence of the Lisomer may simply be the result of a slow inversion rate cannot be excluded, especially when it is found in small quantity. For the frog opioid dermorphin, the all L-containing peptide could not be detected [91]. But in the majority of the cases, peptides containing the L-AA are also present, albeit in smaller quantities. For example, the L/D proportions are 1:4 for frog bombinins [92], 1:2 for spider agatoxins [57] and 1:3 for lobster VIH [62]. Nevertheless, in this latter species, the $\mathrm{CHH}$, another peptide also produced in the sinus gland, displayed an inversion in the ratio L/D with the majority of the peptide being the L-form (3:1) [62]. These ratios were determined by quantifying the isomers purified from organs by chromatography (RP-HPLC). As previously described, cellular studies in crustaceans have been extensively developed, because the Damino acid containing neurohormones are produced in discrete, well-identified neuroendocrine cells located in an easily accessible organ, i.e. a tractable model system. This has enabled more detailed studies aimed at determining the reasons behind the ratio of $\mathrm{CHH} / \mathrm{D}-\mathrm{Ph} \mathrm{P}^{3}-\mathrm{CHH}$ observed on the chromatogram (i.e. 3:1). Indeed, observations of whole mounts of the X-organ using confocal microscopy showed that in crayfish a constant number of 8 cells were found to contain a mixture of $\mathrm{L}-$ and $\mathrm{D}-\mathrm{Phe}^{3}-\mathrm{CHH}$ with a greater abundance of the D-isomer (called D-cells), 
especially in axonal terminals (about 100\%), and approximately 25 cells exclusively synthesised the L-isomer (called L-cells with $100 \%$ of L-isomer [76]). So, proportions of the different isomers estimated using the analytical approach (3:1) and the cellular observations (3 L-cells for 1 D-cell) correlate exactly. Interestingly, at a sub-cellular level, quantification by image analysis using electronic microscopy after double immunogold labelling of L-cells revealed that D-labelling was significantly increased from the cell body to the axon terminal. This was interpreted as a progression in the $\mathrm{Phe}^{3}$ isomerisation process during granule migration within the neurosecretory cell. Accordingly, the proportion in D-cells of granules containing only $\mathrm{CHH}$ was lower in the axon terminals $(5 \%)$ compared with the cell bodies (40\%) [79]. These studies performed at different cellular levels (organ, cell and secretory granule) with various techniques clearly indicate that the conclusions drawn from any ratio measurements should be interpreted with great care depending on the level at which the observation is made.

Different mechanisms for the production of D-AAs in peptides have been proposed since the discovery of the first DAACP in 1981 by Montecucchi et al. [9]. Today, it is generally accepted that this post-translational reaction proceeds by enzymatic action. Free D-AAs can be formed from the corresponding L-enantiomer by the action of amino acid racemases [93,94]. Most of these enzymes require pyridoxalphosphate as a cofactor and the reaction proceeds via a Schiff base as an intermediate. However, another class of racemases operates without any cofactor (in particular, the addition of the pyridoxalphosphate co-factor does not influence the conversion reaction [95]). Examples are the proline, aspartate, and glutamate racemases from different bacteria $[23,96,97]$. Isotope-exchange studies indicated that all the pyridoxalphosphateindependent racemases employed a "two-base" mechanism to catalyse epimerisation, and studies using chemical modifications and site directed mutagenesis revealed that these enzymes utilised their two-cysteinyl residues as the proton abstractor and the proton donor [98]. The reaction catalysed by these enzymes proceeds via deprotonation-protonation at the a-carbon of the substrate (Figure 8) [99]. More precisely, one enzymatic base (i.e. a thiolate group of one cysteinyl residue) deprotonates the substrate, and the conjugate acid of a second enzymatic base (i.e. the thiol group of the other cysteinyl residue) protonates the resulting intermediate from the opposite face [100]. However, the spider-venom isomerase apparently did not contain free SH groups, only disulfide pairings [80], and it was only partly inhibited by $\mathrm{N}$-ethylmaleimide, an alkylating reagent, that covalently modifies nucleophilic thiol residues such as cysteine in proteins [101]. Nevertheless, based on kinetic and isotope exchange experiments, it has been shown that the chiral inversion also proceedes via an exchange of the proton, in this case on the a-carbon of serine-46 of spider $\omega$-agatoxin IVC $[101,102]$. But the residues (not cysteinyl) in the active site of the isomerase, which acted as proton acceptors and donors, respectively, have not yet been identified [10]. As described above, it has been found that the spider-venom isomerase exhibits 
significant homology to serine proteases such as trypsin or chymotrypsin. These two hydrolytic enzymes operate via a "catalytic triad" (His, Asp and Ser) whereby, through hydrogen bonding to a histidine and an aspartic acid, the hydroxyl group of the serine present in the active site is deprotonated and thus becomes a strong nucleophile binding to the carbonyl group of the scissile peptide bond. In the case of the spider isomerase, through a similar "triad", the enzyme serine oxy-anion may act as a strong base abstracting the proton from the substrate (i.e. the $\alpha$-carbon of an AA, e.g. Ser 46 ) most likely generating a planar anionic intermediate [82].

As described above, a second isomerase has been purified from skin secretions of Bombina species [42]. The frog skin enzyme also acts on its substrate via a deprotonation / reprotonation reaction (Figure 8 ). This was demonstrated by carrying out the reaction in the presence of tritiated water. Radioactivity was incorporated into the second AA of the N-terminal heptapeptide sequence of bombinin $\mathrm{H}$ [42]. The peptide side chains, which are present in the active site of the enzyme, are currently not known. As described previously, the comparison of the putative isomerases from different species has shown that a central region, which includes two cysteinyl or two histidyl residues, is highly conserved. The catalytic activity is, however, insensitive to treatment with iodoacetamide; therefore, these cysteinyl residues can be excluded from acting as catalytic bases. In contrast, incubation with diethylpyrocarbonate resulted in loss of activity, which indicates that at least one histidyl residue participates in the catalytic reaction [42].

Similarly, platypus-venom isomerase activity was not inhibited by phenylmethylsulfonyl fluoride or iodoacetamide [68]. These results appear to rule out the presence of a serineprotease-like reactive triad or the involvement of a sulhydryl group (-SH) from a cysteinyl residue in the active site. However, the peptide isomerase was inhibited by diethyl pyrocarbonate. This would suggest the presence of at least one histidyl residue in or near the active site of the enzyme, as has been reported for the peptide isomerase from the frog [42]. Moreover, the candidate gene of platypus isomerase contains two histidyl residues in its central portion (accession number XM_003428816) [68]. On the basis of these studies and similar earlier reports [101], a two-base mechanism has also been proposed for the platypus isomerase with the hypothesis that two histidyl residues are positioned on the opposite sides of the substrate during isomerisation, and they act as a proton abstractor and a proton donor, respectively (Figure 8). During peptide isomerisation, one of the histidyl bases of enzyme deprotonates the a-carbon atom of the second AA (Met) of DLP and forms a planar intermediate [68]. At the same time, the other histidyl base in its conjugated acid form reprotonates the intermediate at the opposite side of the a-carbon atom to form the other isomer. Furthermore, in this study, it was shown that isomerisation of the L- to D-residues in DLP was faster than for the D- to L-reaction. This suggests, that in the two-base mechanism, there is an asymmetry at the active site, in which the 
L-isomer is more favourably positioned for proton abstraction than the D-isomer. In relation to understanding the likely mechanism of the enzyme reactions, two fundamental points appear: (i) identification of a target AA by platypus isomerase in a peptide for isomerisation; (ii) deprotonation and reprotonation of a weakly acidic proton from the a-carbon atom of an AA residue. To summarise, only peptides with a particular sequence will act as substrates and the active site is very specific and restricted to accommodate only certain peptide sequences. The high energy process that involves the removal of a weakly acidic proton by weakly basic catalysts may be explained by the involvement of a high energy hydrogen bonds that results in the formation of tight binding between the enzyme and substrate to produce a relatively stable anionic intermediate [103,104] (central peptide in Figure 8). This outcome can be achieved through the formation of a strong hydrogen bond with the carbonyl carbon of the AA thereby lowering the activation energy barrier for the formation of an enolic intermediate of the bound substrate; this will facilitate the removal of the proton. Alternatively, isomerisation may be a concerted process where incipient carbanion formation, deprotonation, and reprotonation take place simultaneously in the transition state, similar to an $S_{n} 2$-type mechanism that results in inversion of the configuration [68].

To conclude, although it is now clear that an enzymatic activity is involved, the precise mechanism by which the configuration of a specific internal residue is manipulated is still not totally clear. A more accurate understanding of the mechanism should be possible when threedimensional structural data of the enzyme-substrate complex becomes available. To date, the only putative model is the 3D structure of the spider isomerase derived from its primary sequence by homology modelling using the X-ray structure of trypsin (Brookhaven Protein Data Bank code 2PTN, [102]).

\section{What are the structures recognised by such an enzyme? Substrate specificity}

The three isomerases described so far in the literature interconvert in both directions (L->D and $D->L$ ) with variations in L/D ratios and in reaction speeds (reaction rates); for further discussion on the dynamic aspect of isomerisation, see $[68,101,102,105]$.

Since the discovery of the DAACPs in frog skin secretions, the dermorphin with a D-Ala ${ }^{2}$ [9] and the dermenkephalin with a D-Met ${ }^{2}$, several questions concerning the specificity of the isomerisation, and therefore of the isomerase, remain unanswered with respect to a possible regulatory mechanism that ensures recognition of a particular residue within a peptide sequence. In other words, 1) why does the DAA occur in one position rather than another, e.g. D-Met at position 2 but not at pos. 6 in dermenkephalin and D-Phe in pos. 3 but not in pos. 17 in $\mathrm{CHH}$ ? 2) is the nature of the "isomerable" residue crucial?, and 3) do the neighbouring residues influence the isomerised one? The first data towards answering these questions came from Jilek et al. 
[105] To study the substrate specificity of the frog isomerase, they used different AAs at positions 1,2 or 3 of the natural substrate bombinin $\mathrm{H}$ containing an lle at position 2 converted to D-allo$\mathrm{Il}^{2}$. Surprisingly, this enzyme has a rather low selectivity for residues at position 2 where the change of chirality at the $\alpha$-carbon takes place. Indeed, compared to bombinin $\mathrm{H}$ with an $\mathrm{Il}^{2}$, the peptide with $\operatorname{Trp}^{2}$ displayed the same reaction rates and consequently, was also a good substrate Even, five other AAs reacted about ten times faster in the isomerisation reaction, namely methionine, phenylalanine, leucine, norleucine and phenylglycine. Interestingly, the role of the amino terminus for substrate recognition was in contrast crucial one since after replacing the $\alpha$ amino with a hydroxyl group or an acetylated amino group the isomerisation reaction decreased by several orders of magnitude or even did not occur. Likewise, a hydrophobic amino acid at position 1 (lle, Phe or Trp) and a small one at position 3 (Gly) of the substrate are essential. To conclude, the frog isomerase acts exclusively on the second amino acid, while residues 1 and 3 largely define the substrate spectrum of the enzyme. At least, the natural L-forms of dermorphins and deltorphins, were not found because they are unstable and apparently degraded by proteases present in the preparation [42,106-108]. However, a chimeric peptide with the Nterminal tripeptide sequence of deltorphin (Tyr-Met-Phe) linked to the C-terminal end of bombinin (Pro-Val-Leu) plus a cysteinyl residue was sufficiently stable during the assay and was observed to be weakly converted at the $\mathrm{Met}^{2}$ by the Bombina isomerase [105]. Consequently, frog isomerase seems to display a rather low selectivity for the residue at position 2 but an activity influenced by neighbouring residues of the isomerised one.

Furthermore, in view of the rather broad specificity of the frog isomerase, a databank search was made for potential substrates of such an enzyme. Surprisingly, numerous peptides of amphibians and mammals were found which fulfil the requirements determined in this study. For example, alyteserin-2 from the midwife toad Alytes obstetricans [109], several ranalexins, temporins 1DYa and PTa and brevenins 1PTa and 1PTb from diverse Rana species [110,111], hylin a1 from the spotted treefrog (Hypsiboas albopunctatus) [112] as well as kassorin $S$ from the African hyperoliid frog (Kassina senegalensis) [113] were predicted as good substrate candidates for the Bombina isomerase.

Moreover, the substrate spectrum of a recently reported isomerase activity present in the venom of male Platypus is apparently similar to that of the Bombina enzyme $[68,83]$. In delineating the catalytic mechanism of the platypus isomerase and the broader roles in the animal, N-terminal segments of DLP4 and DLP2 (Ile-D-Met-Phe-Phe-....) and natriuretic peptide OvCNP $a$ and $b$ (Leu-D-Leu-His-Asp-...) from the venom were used as substrates. The DLP analogues IMFsrs and IDMFsrs (srs is a solubilising chain) were effective substrates for the isomerase that appeared to recognise the N-terminal tripeptide sequence lle-X-Phe-. 26 mutants of these hexapeptides were synthesized with the second residue (Met) exchanged with another 
amino acid, viz. Ala, $\alpha$-aminobutyric acid, Ile, Leu, Lys, norleucine, Phe, Tyr, and Val. The mutant peptides incorporating norleucine and Phe were effective substrates and exhibited L- or Disomerisation, but mutant peptides that contained residues with shorter, $\beta$-branched or long side chains with polar terminal groups, viz. Ala, a-aminobutyric acid, Ile, Val, Leu, Lys, and Tyr, respectively, were not found to be substrates. It was also demonstrated that at least three $\mathrm{N}$ terminal amino acyl residues are absolutely essential for L- to D-isomerisation and the third residue must be a Phe. Contrary to DLP, none of the hexapeptides based on Leu-Leu-His, the first three residues of OvCNP, were substrates. To conclude, platypus isomerase appeared to recognise the $\mathrm{N}$-terminal tripeptide sequence Ile-X-Phe- with specific characteristics of the residue $\mathrm{X}$.

Moreover, it was established that the spider enzyme catalysing isomerisation, i.e. Agelenopsis isomerase had a minimum substrate recognition site, which is a tetrapeptide (-LeuSer-Phe-Ala) corresponding to the C-terminus of the spider $\omega$-agatoxin IVC with a L-Ser ${ }^{46}$ (48 AAs). The enzyme targeted various peptides with serine methyl ester and Cys instead of $\operatorname{Ser}^{46}$, and was able to weakly isomerise Ala but not Thr (e.g. X in Ac-Met-Glu-Gly-Leu-X-Phe-Ala-OH) [101]. No other natural peptide is known in this spider and no other heterologous peptide has been tested for this isomerase.

At least, the examples of $\mathrm{D}-\mathrm{Ph} \mathrm{P}^{3}-\mathrm{CHH}$ and $\mathrm{D}-\mathrm{Trp}^{4}-\mathrm{VIH}$ in lobster raise the question of the substrate specificity of the putative isomerase(s). Indeed, the same cells and even the same secretory granules, contained both DAACPs but axon terminals never exhibited simultaneous labelling for $\mathrm{CHH} / \mathrm{D}-\mathrm{Trp}^{4}-\mathrm{VIH}$ or $\mathrm{VIH} / \mathrm{D}-\mathrm{Phe}^{3}-\mathrm{CHH}$ [62]. So, a unique enzyme might act on both hormones. Nevertheless, these peptides display a D-residue of different natures (Phe or Trp) and at different positions ( 3 or 4 ), hence the isomerisation by two distinct enzymes, one for each peptide type, should also be considered. It is and will remain an enigma until the characterisation and identification of the putative peptide isomerase(s) contained in these specialised cells of the $X$ organ-sinus gland complex of lobster. To date, the occurrence of two distinct enzymes with different substrate specificities and a variable expression pattern appears as the most likely working hypothesis.

To conclude, even if the neighbouring AAs must have particular characteristics, especially regarding polarity and charge, these enzymes display a relatively broad specificity for the type of isomerised residue. It even seems that, at least for the frog isomerase, that heterologous peptides can be substrates. The expression of isomerases with similar characteristics in other species can therefore be expected to catalyse the formation of DAACPs. Nevertheless, in each species, a single isomerase seems to be insufficient, as the currently isolated and characterised enzymes do not interconvert potentially isomerisable peptides (e.g. dermorphin in frog and natriuretic peptide in platypus). Moreover, even if the position of the isomerised residue has not 
been extensively studied, it is notable that only one D-AA is found in each peptide chain, and it is always close to one end, most frequently near the N-terminus (position 2,3 or 4), but also near the C-terminus ( $n-2)$ but never at the extremities (1 or $n$ ). This is why, in our opinion, the substrate spectrum of the enzyme is largely defined by residues neighbouring the isomerised one. This hypothesis is supported by the fact that dermenkephalin and DLP DLP4 contain a DMet $_{2}$ and not a D-Met 6 . In the same way, the octapeptide contryphan from the venom of a fishhunting snail contains tryptophan residues at positions 4 and 7 , of which the first is in the Dconfiguration, while the second is the 6-bromo-derivative of this amino acid [114,115].

\section{Conclusion and future issues}

In the present paper, we gathered the current knowledge concerning the biogenesis of DAACPs (in a large sense) in the living world, by describing the occurrence of the peptides, the spatio-temporal and mechanistic aspects of isomerisation at the cell level and, the specific enzyme(s) involved in this maturation step, the peptidyl aminoacyl L-D isomerase.

Since the discovery in the 30 s of a D-AA in bacterial proteins, numerous examples of Damino acyl residues of different natures and at different positions in the peptide chain were characterised in invertebrates (molluscs, arachnids, crustaceans) and vertebrates (platypus, frogs and humans). More surprisingly, a weak isomerase activity has also been reported for the first time in a plant (papaya), suggesting the presence of a DAACP. Consequently, the phylogenetic distance between these species suggests that every living organism may own some peptide isomerase activity. Moreover, at the tissue level, specialised cells were observed for isomerisation of peptides in several crustaceans and in Aplysia, a gasteropod mollusc, suggesting a cellular specificity of isomerase. In this context of specificity, a recent concept of mechanism of metabolite separation named "chiral compartmentation", that emerged from the stereo-specificity of enzymes for theirs substrate(s) must also be now taken into consideration [69].

Biosynthesis of DAACPs has been shown to occur by several ways, by the incorporation of D-AAs during translation or isomerisation of the L-AA generated by a normal codon after the building of the peptide or the protein via a non-enzymatic pathway (for e.g. a-crystallin) or by specific isomerase(s) which apparently acts after the cleavage of the precursor. On the basis of current studies on isomerase from frog, spider and platypus, a two-base mechanism has been proposed for L- to D-conversion with the hypothesis that two residues (e.g. histidyl) in the active site (e.g. a catalytic triad) are positioned on the opposite sides of the substrate during isomerisation, and that they act as a proton abstractor and a proton donor, respectively. At least, even if the neighbouring AAs of the isomerised residue must have particular characteristics, especially for polarity and charge, these enzymes display a relatively broad specificity for the type 
of isomerised residue, contrary to what was originally thought.

Even if the number of DAACPS discovered is growing each year, too little is known about the characteristics of peptidyl aminoacyl L-D isomerisation, one of the most unusual and fascinating posttranslational modifications. This review opens up fascinating perspectives in understanding of isomerisation processes:

1- One of the major challenges remaining for the future is the identification of the receptors of DAACPs and their L-counterpart, when it is present in the tissue, aiming to provide insights on the functional significance of isomerisation.

2- More information about the mechanism of this modification is needed. A more accurate understanding should be possible when three-dimensional structural data on the isomerase(s)substrate complex will be available.

3- Increasing awareness of the presence of a D-AA in proteins in the otherwise dominant 'L-chiral biosphere' is largely due to recent developments in rapidly-applicable, analytical-chemical methods. Nevertheless, in spite of efforts over the last decade, especially with the development of abundant direct and indirect chromatographic methods for the enantioseparation and stereochemical assignment of D- and L-AAs e.g. in hydrolysates of isolated peptides, identification of DAACPs remains a challenging task. Indeed, isomerisation does not induce any change in the primary sequence or in physicochemical properties of the molecule such as molecular mass or in pl. Moreover, as it has been shown for DLP2 and DLP4 from platypus venom, the overall fold of the full-length protein is not substantially changed, despite of the retention time difference observed in RP-HPLC (Figure 9) [66]. As a consequence, it may be speculated that many DAACPs present in animal tissues remain unknown, though they might well be of great physiological or pathological relevance. Therefore, the development of proper analytical methods for detecting the presence of a D-residue in a peptide/protein is obviously valuable, and especially for a high-throughput screening of complex mixture of peptides by proteomic approach. To date, analysis with synthetic peptides by mass spectrometry gave interesting results. This method seems to be promising to go deeper in the characterisation of natural peptides. Finally, an interesting alternative approach for DAACP characterisation could be identification of isomerase orthologous sequences in genomic and transcriptomic data sets obtained from an increasing number of animals, bacteria and even plants.

\section{Acknowledgments}

We are grateful to Dr Melody S. Clark (British Antarctic Survey, Natural Environment Research Council, Cambridge, United Kingdom) for critical reading of the manuscript. 


\section{Legends of figures}

Table 1. D-amino acid containing proteins observed in various tissues of the living body. Reprinted from Fuji et al. [34] with permission.

Table 2. Peptides with a D-amino acid residue isolated from eukaryotic tissues. The list is not exhaustive. The D-residue is in bold and italics. The bombinin with the asterisk is an antimicrobial peptide. Both isomers of $\mathrm{CHH}$ display hyperglycaemic activity whereas $\mathrm{D}-\mathrm{Ph} \mathrm{P}^{3}-\mathrm{CHH}$ also presents osmoregulatory and molt-inhibitory effects. VIH is an inhibitor of vitellogenin synthesis whereas the function of $\mathrm{D}-\mathrm{Trp}^{4}-\mathrm{VIH}$ is unknown. Reprinted and adapted from Soyez et al. [116] with permission.

Table 3. Consequences of a single amino-acid residue isomerisation on the biological activity of the peptides. Numbers and letters in brackets refers to the text. 0 for no biological activity compared to that of the counterpart; - for a slight biological activity compared to the counterpart; + for biological activity which is as high as that of the counterpart.

Figure 1. Biosynthesis of the terminal peptidoglycan stem peptide of Gram-negative bacteria. The chirality of the $\alpha$-carbon of two L-alanine (L-Ala) is inverted from the L- to the D-configuration by alanine racemase (Alr). The two D-alanine (D-Ala) are ligated together by D-alanine-D-alanine ligase $(\mathrm{Ddl})$ and the dipeptide $\mathrm{D}$-alanyl-D-alanine (DA-DA) is subsequently added to the stem tripeptide (L-Ala-D-Glu-m-DAP) by a UDP-N-acetylmuramoyl-tripeptide-D-alanyl-D-alanine ligase (MurF) resulting in a pentapeptide. m-DAP, meso-diaminopimelic acid; MurNAc,N-acetylmuramic acid; UDP, uridine diphosphate. Reprinted and adapted from Liechti et al. [117] with permission.

Figure 2. Monomeric structure of the bacteria Streptomyces lavendulae alanine racemase dimer. The two subunits that form the monomer structure are shown in different colors ( $\alpha$-helices colored red and $\beta$-sheets colored blue). The pyridoxal 5'-phosphate shown in green (PLP) is covalently bound to Lys $_{38}$ to form a PLP-binding residue (N'-pyridoxyl-lysine-5'-monophosphate) that resides in the active site. The active site is composed of residues from the $\alpha / \beta$ barrel domain of one monomer and residues from the $\beta$-strand domain of the other monomer. Reprinted from Noda et al. [118] with permission.

Figure 3. Biosynthesis of penicillin $\mathrm{G}$ by the fungus Penicillium chrysogenum. The first step in the biosynthesis of penicillin $G$ is the condensation of two amino acids, L-amino-adipic acid and Lcysteine. Then, a, L-valine is added to the two residues and epimerised to the D-form to generate the L-L-D-tripeptide, i.e. $\delta$-(L- $\alpha-A m i n o a d i p y l)-L-C y s-D-V a l$ (ACV-tripeptide) by a catalytic multienzyme, $\delta$-(L-a-aminoadipyl)-L-Cys-D-Val synthetase (AVCS) that displays an epimerase domain in its $\mathrm{C}$-terminal region. The following steps are the oxidative conversion of linear ACV-tripeptide 
into the bicyclic intermediate isopenicillin $\mathrm{N}$ by isopenicillin $\mathrm{N}$ synthase (INPS) and a transamidation by isopenicillin acyltransferase (IAT) to produce penicillin $\mathrm{G}$.

Figure 4. A. Structure of $\operatorname{Ltn}-\alpha$ and $\operatorname{Ltn}-\beta$ of the lantibiotic lacticin 3147 , with the 23 posttranslationally modified residues shaded gray. The locations of the three D-alanine residues are indicated by black circles. B. The proposed pathway for the conversion of L-serine to Dalanine via dehydroalanine (Dha) is also depicted. LtnM is a lantibiotic synthetase required to dehydrate serines. LtnJ is a lantibiotic dehydrogenase to generate D-alanines. Reprinted and adapted from Cotter et al. [31] with permission.

Figure 5: Reaction pathways for spontaneous inversion and isomerisation of aspartyl residues in peptides/proteins. The formation of $D$ - and $\beta$-aspartyl residues (named $D-\beta$-Asp) from aspartyl residues in this protein begins (1) with the attack of the carbonyl group in the side chain of the Laspartyl residue by the nitrogen of the amino acid residue following the Asp residue. Lsuccinimide is formed by intramolecular cyclisation and (2) is converted to D-succinimide through an intermediate [enol form] whose prochiral $\alpha$-carbon is in the plane of the ring. (3) Protonation of the intermediate may proceed from the upper or lower side of the plane in an ordinary peptide or protein. The area surrounding Asp-151 and Asp-58 residues in aA-crystallin is thought to form a chiral environment that promotes formation of D-succinimide over L-succinimide. (4) D- and Lsuccinimide are hydrolysed at either side of their two carbonyl groups, yielding both $\beta$ - and $\alpha$-Asp residues. As shown in Figure 5, D-Asp formation is also accompanied by isomerisation from the natural $\alpha$-Asp to the biologically rare $\beta$-Asp (isoaspartate). Thus, four isomers, L-Asp, L- $\beta$-Asp, DAsp and D- $\beta$-Asp, are simultaneously formed in the protein. Reprinted and adapted from Takahashi et al. [40] with permission.

Figure 6. Confocal micrographs of double immunolabelled whole mounts of crustacean X organsinus gland. Images were collected as a focal series and processed to create 2D projections (single composite images). Central drawing: schematic representation of the eyestalk nervous structures and the neuroendocrine complex ( $X$ organ-sinus gland). OX, $X$ organ; SG, sinus gland; R, retina; LG, lamina ganglionaris; ME, medulla externa; MI, medulla interna; MT, medulla terminalis. (A) Distribution of $\mathrm{CHH}$ cells in $\mathrm{X}$ organ of the crayfish Orconectes limosus, showing green cell bodies ( $\mathrm{L}-\mathrm{CHH}$ cells) labelled only with gp-anti-pQL, synthesising $\mathrm{CHH}$, specific of $\mathrm{CHH}$ and orange somata ( $\mathrm{D}-\mathrm{CHH}$ cells) corresponding to labelling with gp-anti-pQL and rb-antipQD antisera, producing both isomers of $\mathrm{CHH}, \mathrm{CHH}$ and $\mathrm{D}-\mathrm{Phe}^{3}-\mathrm{CHH}$, specific of D-Phe ${ }^{3}-\mathrm{CHH}$. (B) Enlarged view of L-CHH cells (green) and $\mathrm{D}-\mathrm{CHH}$ cells showing the different granule cluster colorations (green, orange and red) and the axon appearing in red (arrow). (C) Distribution of 
$\mathrm{CHH}$ cells in $\mathrm{X}$ organ of the lobster Homarus americanus showing green cell bodies (L-CHH cells) labelled only with gp-anti-pQL and orange somata ( $\mathrm{D}-\mathrm{CHH}$ cells) corresponding to labelling with gp-anti-pQL and rb-anti-pQD antisera. (D) General view of $X$ organ labelled with $r$-anti-L, specific of $\mathrm{VIH}$ (red) and gp-anti-DW4, specific of D-Trp ${ }^{4}$-VIH (green) to visualise small L-VIH cells (red producing $\mathrm{VIH}$ ) and larger D-VIH cells (green or yellow) synthesising both isomers of $\mathrm{VIH}, \mathrm{VIH}$ and $\mathrm{D}-\mathrm{Trp}_{4}-\mathrm{VIH}$. (E) Immunolocalisation of $\mathrm{D}-\mathrm{Trp}^{4}-\mathrm{VIH}$ and $\mathrm{D}-\mathrm{Phe}^{3}-\mathrm{CHH}$ in the $\mathrm{X}$ organ where three cell types were observed: $\mathrm{D}-\mathrm{CHH}$ cells producing only D-Phe ${ }^{3}-\mathrm{CHH}$ (red, thin arrow), D-VIH cells containing only D-Trp ${ }^{4}-\mathrm{VIH}$ (green, short arrow) and D-cells producing both D-isomers (orange, long arrows). Reprinted and adapted from Ollivaux et al. [62] and Soyez et al. [76] with permission.

Figure 7. General diagram of precursor processing of $\mathrm{VIH}$ and $\mathrm{CHH}$ isomers in relation to the different cell types in $\mathrm{X}$ organ-sinus gland complex. CPRP, $\mathrm{CHH}$ precursor related peptide; $\mathrm{CHH}$ VIH, L-CHH and L-VIH cells D-CHH and D-VIH cells.

${ }^{a}$ Amidation can be pre-, co- or post-cleavage of CPRP.

${ }^{\mathrm{b}}$ Cylisation of $\mathrm{CHH} \mathrm{N}$-terminus is optional (N-terminus unblocked $\mathrm{CHH}$ can be released) and, similar to isomerisation, it occurs after CPRP cleavage.

${ }^{c} \mathrm{By}$ contrast to $\mathrm{CHH}, \mathrm{VIH}$ is not N-terminal cyclised. L-CHH and L-VIH cells secrete exclusively $\mathrm{CHH}$ and $\mathrm{VIH}$, respectively, whereas $\mathrm{D}-\mathrm{CHH}$ and $\mathrm{D}-\mathrm{VIH}$ cells release mainly the $\mathrm{D}$-isomer of the respective hormone, in addition to a variable amount of L-isomer. D-cells secrete mainly the $D$ form of both $\mathrm{CHH}$ and $\mathrm{VIH}$. Besides isomerisation, the same post-translational modifications occur in every type of $\mathrm{CHH}$ or $\mathrm{VIH}$ cell. L-CHH cells, cells synthesising $\mathrm{CHH}$; D-CHH cells, cells producing both isomers of $\mathrm{CHH}, \mathrm{CHH}$ and D-Phe ${ }^{3}-\mathrm{CHH}$; L-VIH cells, cells synthesising VIH; DVIH cells, cells producing both isomers of $\mathrm{VIH}, \mathrm{VIH}$ and $\mathrm{D}-\mathrm{Trp}^{4}-\mathrm{VIH}$; D-cells, cells producing both D-isomers (D-Phe ${ }^{3}-\mathrm{CHH}$ and D-Trp ${ }^{4}-\mathrm{VIH}$ ). Reprinted from Ollivaux et al. [62] with permission.

Figure 8. A two-base mechanism is proposed for the peptide isomerase. Abstraction of a proton from one face of an activated $\alpha$-carbon atom by one enzymatic base (B:) is concomitant with delivery from the opposite face by the conjugate acid of a second enzymatic base (BH). aa: amino acid. Reprinted and adapted from Bansal et al. [68] with permission.

Figure 9. Structure of Defensin Like Peptide isomers (DLP2 and DLP 4). (A) Ribbon diagram of DLP2 structure showing the secondary-structural elements and disulfide connectivities. (B) Ribbon diagram of DLP4 showing the secondary-structural elements and disulfide connectivities. (C) Superposition of DLP2 (grey) and DLP4 (red) structures over the backbone of residues 7-42. Only the polypeptide backbone chains are shown. Reprinted and adapted from Torres et al. [66] 
with permission.

http://mc.manuscriptcentral.com/jpsc 


\begin{tabular}{llll}
\hline Tissue & Protein & Amino acid & Disease \\
\hline Teeth & Phosphophoryn & D-Asp & $?$ \\
Bone & Osteocalcin & D -Asp & $?$ \\
Aorta & Elastin & D -Asp & Arteriosclerosis \\
Brain & B-Amyloid & D-Asp, D-Ser & Alzheimer \\
Brain & a-synuclein & D-Asp & Parkinson \\
Lens & aA, AB-crystallin & D-Asp & Cataract \\
Retina & $\alpha$ & D-Asp & AMD \\
Conjutivae & $?$ & D-Asp & Pingueculae \\
Cornea & $?$ & D-Asp & CDK \\
Skin & Elastin & D-Asp & Elastosis \\
& Keratin & D-Asp & Sun damage \\
Lung & Elastin & D-Asp & $?$ \\
Intestine & $?$ & D-Asp & $?$ \\
\hline${ }^{a}$ AMD: age-related macular degeneration & \\
${ }^{b}$ CDK: climatic droplet keratopathy &
\end{tabular}


Table 2

\begin{tabular}{|c|c|c|}
\hline Peptide [reference] & Sequence & Organism \\
\hline \multicolumn{3}{|c|}{ Frog skin opïoids and *antibacterial peptides } \\
\hline Dermorphin [9] & Tyr-Ala-Phe-Gly-Tyr-Pro-Ser-NH ${ }_{2}$ & Phyllomedusa sauvagei \\
\hline Met-Deltorphin [119] or & Tyr-Met-Phe-His-Leu-Met-Asp-NH ${ }_{2}$ & Phyllomedusa bicolor \\
\hline Dermenkephalin [51] & & Phyllomedusa sauvagei \\
\hline Deltorphins I/II [13] & Tyr-Ala-Phe-Asp/Glu-Val-Val-Gly-NH & Phyllomedusa bicolor \\
\hline Leu-Deltorphin [120] & Tyr-Leu-Phe-Ala-Asp-Val-Ser-.... & Phyllomedusa burmeisteri \\
\hline *Bombinin H [92] & Ile-alle-Gly-Pro-Val-Leu-Gly-... & Bombina variegata \\
\hline \multicolumn{3}{|l|}{ Spider venom toxins } \\
\hline$\omega$-Agatoxin $[45,121]$ & $\ldots$-Gly-Leu-Ser ${ }_{46}$-Phe-Ala & Agelenopsis aperta \\
\hline \multicolumn{3}{|l|}{ Mollusc venom toxins } \\
\hline Conotoxin R11a [122] & ...-Ser-Phe-Phe ${ }_{44}$-Lys-lle & Conus radiatus \\
\hline Conotoxin R11c [123] & $\ldots$-Ser-Phe-Leu ${ }_{42}$-Thr & Conus radiatus \\
\hline Bromocontryphan-R [115] & Gly-Cys-Hyp-Trp-Glu-Pro-Trp & Conus radiatus \\
\hline Contryphan [47] & Gly-Cys-Hyp-Trp-Glu-Pro-Trp-Cys-NH ${ }_{2}$ & Conus radiatus \\
\hline Contryphan-P [124] & Gly-Cys-Pro-Trp-Asp-Pro-Trp-Cys- $\mathrm{NH}_{2}$ & Conus radiatus \\
\hline Contryphan-R [124] & Gly-Cys-Hyp-Trp-Glu-Pro-Trp-Cys- $\mathrm{NH}_{2}$ & Conus radiatus \\
\hline Contryphan-Sm ([124] & Gly-Cys-Hyp-Trp-Gln-Pro-Trp-Cys-NH ${ }_{2}$ & Conus stercusmuscarum \\
\hline Contryphan-Tx [48] & Gly-Cys-Hyp-Trp-Gln-Pro-Tyr-Cys-NH ${ }_{2}$ & Conus textile \\
\hline Leu-Contryphan-P [125] & Gly-Cys-Val-Leu-Leu-Pro-Trp-Cys & Conus purpurascens \\
\hline Leu-Contryphan-Tx [48] & Cys-Val-Leu-Tyr-Pro-Trp-Cys-NH ${ }_{2}$ & Conus textile \\
\hline Des-(Gly $\left.{ }^{1}\right)$ Contryphan-R [47] & Cys-Hyp-Trp-Glu-Pro-Trp-Cys-NH ${ }_{2}$ & Conus radiatus \\
\hline Conomap-Vt [126] & Ala-Phe-Val-Lys-Gly-Ser-Ala-Gln-Arg-Val-Ala-His-Gly-Tyr & Conus vitulinus \\
\hline Conomarphin [127] & Asp-Trp-Glu-Tyr-His-Ala-His-Pro-Lys-Hyp-Asn-Ser-Phe-Trp-Thr & Conus marmoreus \\
\hline Conophan [128] & Ala-Hyp-Ala-Asn-Ser-Val-Trp-Ser & Conus vitulinus \\
\hline \multicolumn{3}{|l|}{ Mammal venom toxins } \\
\hline OvCNP [129] & Leu-Leu-His-Asp-His-Pro-Asn-.... & Ornithorhyncus anatinus \\
\hline DLP2 [66] & Ile-Met-Phe-Phe-Glu-Met-... & Ornithorhyncus anatinus \\
\hline \multicolumn{3}{|c|}{ Mollusc neuroexcitatory peptides } \\
\hline Achatin [56] & Gly-Phe-Ala-Asp & Achatina fulica \\
\hline Fulicin [130] & Phe-Asn-Glu-Phe-Val-NH ${ }_{2}$ & Achatina fulica \\
\hline Fulyal [131] & Tyr-Ala-Glu-Phe-Leu-NH ${ }_{2}$ & Achatina fulica \\
\hline FFRFa [55] & Ala-Leu-Ala-Gly-Asp-His-Phe-Phe-Arg-Phe--NH & Mytilus edulis \\
\hline NdWFa [53] & Asp-Trp-Phe-NH ${ }_{2}$ & Aplysia kurodai \\
\hline Ocp-1/4 [132] & Gly-Phe-Gly-Asp/Gly-Ser-Trp-Asp & Octopus minor \\
\hline \multicolumn{3}{|l|}{ Crustacean neurohormones } \\
\hline $\mathrm{CHH}[58]$ & pGIn-Val-Phe-Asp-Glu-Ala-Cys.... & Astacidea \\
\hline VIH [62] & Ala-Ser-Ala-Trp-Phe-Thr-Asn... & Homaridea \\
\hline
\end{tabular}




\begin{tabular}{lcc}
\hline Peptide & L-isomer & D-isomer \\
\hline (1) Only D-isomer has been described: & & \\
(a) Dermorphin/dermenkephalin & 0 & + \\
(b) Fulicin & - & + \\
(c) Mytilus-FFRFamide & + & + \\
(2) Both isomers are present: & 0 & + \\
(a) Achatin & - & + \\
(b) W-agatoxin & - & + \\
(c) CHH hyperglycaemic activity & 0 & + \\
$\quad \quad$ molt inhibition & 0 & + \\
(d) VIH osmoregulation & + & 0 \\
(e) OvCNP & + & + \\
\hline
\end{tabular}




\section{References}

1. Morizawa K. The extractive substances in Octopus octopodia. Acta Scholae Medicinalis Universitatis Imperialis in Kyoto. 1927; 9: 285-298.

2. Moore W, Wilson DW. Nitrogenous extractives of scallop muscle. I. The isolation and study of the structure of octopine. J. Biol. Chem. 1937; 119: 537-584.

3. Ivanovics G, Bruckner V. Ober die chemische natur der immunspezifischen kapselsubstanz der milzbrandbazillen. Die Natuurwissenschaften. 1937; 25: 250.

4. Bodanszky M, Perlman D. Origin of D-amino-acids in microbial peptides: rule of $\alpha$ epimerization. Nature. 1968; 218: 291-292.

5. Helfman PM, Bada JL. Aspartic acid racemization in tooth enamel from living humans. Proc. Natl. Acad. Sci. USA. 1975; 72: 2891-2894.

6. Fujii N, Satoh K, Harada K, Ishibashi Y. Simultaneous stereoinversion and isomerization at specific aspartic acid residues in $\alpha$ A-crystallin from human lens. J. Biochem. 1994; 116: 663-669.

7. Roher AE, Lowenson JD, Clarke S, Wolkow C, Wang R, Cotter RJ, Reardon IM, ZurcherNeely HA, Heinrikson RL, Ball MJ, Greenberg BD. Structural alterations in the peptide backbone of $\beta$-amyloid core protein may account for its deposition and stability in Alzheimer's disease. J. Biol. Chem. 1993; 268: 3072-3083.

8. Fujii N, Momose $\mathrm{Y}$, Ishii N, Takita M, Akaboshi M, Kodama M. The mechanisms of simultaneous stereoinversion, racemization, and isomerization at specific aspartyl residues of aged lens proteins. Mech. Ageing Dev. 1999; 107: 347-358, S0047637498001298.

9. Montecucchi PC, De Castiglione R, Piani S, Gozzini L, Erspamer VR. Amino acid composition and sequence of dermorphin, a novel opiate-like peptide from the skin of Phyllomedusa sauvagei. Int. J. Peptide Protein Res. 1981; 17: 275-283.

10. Jilek A, Kreil G. D-amino acids in animal peptides. Monatshefte für Chemie - Chemical Monthly. 2008; 139: 1-5, 10.1007/s00706-007-0780-5.

11. Bai L, Sheeley S, Sweedler JV. Analysis of endogenous D-amino acid-containing peptides in Metazoa. Bioanal. Rev. 2009; 1: 7-24, 10.1007/s12566-009-0001-2.

12. Richter K, Egger R, Kreil G. D-alanine in the frog skin peptide dermorphin is derived from Lalanine in the precursor. Science. 1987; 238: 200-202.

13. Erspamer V, Melchiorri P, Falconieri-Erspamer G, Negri L, Corsi R, Severini C, Barra D, Simmaco M, Kreil G. Deltorphins; a family of naturally occuring peptides with high affinity and selectivity for $\partial$ opiod binding sites. Proc. Natl. Acad. Sci. USA 1989; 86: 5188-5192.

14. Soyez D, in Recent Advances in Marine Biotechnology (Eds: Fingerman $M$, Nagabhushanam R) Science Publishers, Plymouth, 2003, pp. 280-301.

15. Tao Y, Quebbemann NR, Julian RR. Discriminating D-amino acid-containing peptide epimers by radical-directed dissociation mass spectrometry. Anal. Chem. 2012; 84: 6814-6820, 10.1021/ac3013434.

16. Bai L, Romanova EV, Sweedler JV. Distinguishing endogenous D-amino acid-containing neuropeptides in individual neurons using tandem mass spectrometry. Anal. Chem. 2011; 83: 2794-2800, 10.1021/ac200142m.

17. Sachon E, Clodic G, Galanth C, Amiche M, Ollivaux C, Soyez D, Bolbach G. D-amino acid detection in peptides by MALDI-TOF-TOF. Anal. Chem. 2009; 81: 4389-4396, 10.1021/ac9002886.

18. Munegumi T. Hydrophobicity of peptides containing D-amino acids. Chem. Biodivers. 2010; 7: 1670-1679, 10.1002/cbdv.200900370.

19. Mclntosh JA, Donia MS, Schmidt EW. Ribosomal peptide natural products: bridging the ribosomal and nonribosomal worlds. Nat. Prod. Rep. 2009; 26: 537-559.

20. Kandler O, SchleiferK H, Dandl R. Differentiation of Streptococcus faecalis Andrewes and Horder and Streptococcus faecium Orla-Jensen Based on the amino acid composition of their murein. J. Bacteriol. 1968; 96: 1935-1939.

21. Trippen B, Hammes WP, Schleifer KH, Kandler O. Mode of action of D-amino acids on the biosynthesis of peptidoglycan. Arch. Microbiol. 1976; 109: 247-261. 
22. Lovering AL, Safadi SS, Strynadka NC. Structural perspective of peptidoglycan biosynthesis and assembly. Annu. Rev. Biochem. 2012; 81: 451-478, 10.1146/annurev-biochem-061809112742.

23. Adams E. Catalytic aspects of enzymatic racemization. Adv. Enzymol. Relat. Areas Mol. Biol.1976; 44: 69-138.

24. Shaw J, Petsko G, Ringe D. Determination of the structure of alanine racemase from Bacillus stearothermophilus at 1.9-A resolution. Biochemistry. 1997; 36: 1329-1342.

25. Schoenhusen U, Voigt U, Hennig J, Kuhla S, Zitnan R, Souffrant W-B. Bacterial D-alanine concentrations as a marker of bacterial nitrogen in the gastrointestinal tract of pigs and cows. Veterinarni Medicina. 2008; 53: 184-192.

26. Weber SS, Polli F, Boer R, Bovenberg RAL, Driessen AJM. Increased Penicillin Production in Penicillium chrysogenum Production Strains via Balanced Overexpression of Isopenicillin $\mathrm{N}$ Acyltransferase. Appl. Environ. Microbiol. 2012; 78: 7107-7113.

27. Wu XB, Garcia-Estrada C, Vaca I, Martin JF. Motifs in the C-terminal region of the Penicillium chrysogenum ACV synthetase are essential for valine epimerization and processivity of tripeptide formation. Biochimie. 2012; 94: 354-364.

28. Schofield C, Baldwin J, Byford M, Clifton I, Hajdu J, Hensgens C, Roach P. Proteins of the penicillin biosynthesis pathway. Curr. Opin. Struct. Biol. 1997; 7: 857-864.

29. Ozcengiz G, Demain AL. Recent advances in the biosynthesis of penicillins, cephalosporins and clavams and its regulation. Biotechnol. Adv. 2012; 10.1016/j.biotechadv.2012.12.001.

30. Skaugen M, Nissen-Meyer J, Jung G, Stevanovic S, Sletten K, Inger Mortvendt Abilgaard C, Nest IF. In vivo conversion of L-serine to D-alanine in a ribosomally synthesized polypeptide. J. Biol. Chem. 1994; 44: 27183-27185.

31. Cotter PD, O'Connor PM, Draper LA, Lawton EM, Deegan LH, Hill C, Ross RP. Posttranslational conversion of L-serines to D-alanines is vital for optimal production and activity of the lantibiotic lacticin 3147. Proc. Natl. Acad. Sci. USA. 2005; 102: 18584-18589, Doi 10.1073/Pnas.0509371102.

32. Ryan MP, Jack RW, Josten M, Sahl HG, Jung G, Ross RP, Hill C. Extensive posttranslational modification, including serine to D-alanine conversion, in the two-component lantibiotic, lacticin 3147. J. Biol. Chem. 1999; 274: 37544-37550, Doi 10.1074/Jbc.274.53.37544. 33. Suda S, Lawton EM, Wistuba D, Cotter PD, Hill C, Ross RP. Homologues and Bioengineered Derivatives of LtnJ Vary in Ability to Form D-Alanine in the lantibiotic Lacticin 3147. J. Bacteriol. 2012; 194: 708-714, Doi 10.1128/Jb.06185-11.

34. Fujii N, Kaji Y, Fujii N. D-Amino acids in aged proteins: Analysis and biological relevance. $J$ Chromatogr. B Analyt. Technol. Biomed. Life Sci. 2011; 879: 3141-3147, Doi 10.1016/J.Jchromb.2011.05.051.

35. Kaneko I, Yamada N, Sakuraba Y, Kamenosono M, Tutumi S. Suppression of mitochondrial succinate-dehydrogenase, a primary target of $\beta$-amyloid, and its derivative racemized at ser residue. J. Neurochem. 1995; 65: 2585-2593.

36. Demarchi B, Collins M, Bergstrom E, Dowle A, Penkman K, Thomas-Oates J, Wilson J. New experimental evidence for in-chain amino acid racemization of serine in a model peptide. Anal. Chem. 2013; 85: 5835-5842.

37. Fujii N, Ishibashi $\mathrm{Y}$, Satoh K, Fujino M, Harada K. Simultaneous racemization and isomerization at specific aspartic acid residues in $\alpha B$-crystallin from the aged human lens. Biochim. Biophys. Acta. 1994; 1204: 157-163.

38. Fujii N. D-amino acids in living higher organisms. Orig. Life Evol. Biosph. 2002; 103-127.

39. Fujii N, Matsumoto S, Hiroki K, Takemoto L. Inversion and isomerization of Asp-58 residue in human $\alpha \mathrm{A}$-crystallin from normal aged lenses and cataractous lenses. Biochim. Biophys. Acta. 2001; 1549: 179-187.

40. Takahashi O, Kobayashi K, Oda A. Modeling the enolization of succinimide derivatives, a key step of racemization of aspartic acid residues: importance of a $\mathrm{two}^{-} \mathrm{H}_{2} \mathrm{O}$ mechanism. Chem. Biodivers. 2010; 7: 1349-1356. 
41. Geiger T, Clarke S. Deamidation, isomerization, and racemization at asparaginyl and aspartyl residues in peptides - succinimide-linked reactions that contribute to protein degradation. J. Biol. Chem. 1987; 262: 785-794.

42. Jilek A, Mollay C, Tippelt C, Grassi J, Mignogna G, Mullegger J, Sander V, Fehrer C, Barra $D$, Kreil G. Biosynthesis of a D-amino acid in peptide linkage by an enzyme from frog skin secretions. Proc. Natl. Acad. Sci. USA. 2005; 102: 4235-4239.

43. Kreil G. D-amino acids in animal peptides. Annu. Rev. Biochem.1997; 66: 337-345.

44. Kreil G. Peptides containing a D-amino acid from frogs and molluscs. J. Biol. Chem. 1994; 269: 10967-10970.

45. Kuwada M, Teramoto T, Kumagaye KY, Nakajima K, Watanabe T, Kawai T, Kawakami Y, Niidome T, Sawada K, Nishizawa Y, Katayama K. $\omega$-agatoxin-TK containing D-Serine at position 46 , but not synthetic $\omega$-L-Ser ${ }_{46}$ agatoxin-TK, exerts blockade of P-type calcium channels in cerebellar Purkinje neurons. Molec. Pharmacol. 1994; 46: 587-593.

46. Heck SD, Siok CJ, Kelbaugh PR, Thadeio PF, Welch MJ, Williams RD, Ganong AH, Kelly ME, Lanzetti AJ, Phillips D, Ahlijanian MK. Functional consequences of posttranslational isomerization of $\mathrm{Ser}_{46}$ in a calcium-channel toxin. Science. 1994; 266: 1464-1464.

47. Jimenéz EC, Oliviera BM, Gray WR, Cruz LJ. Contryphan is a D-tryptophan-containing Conus peptide. J. Biol. Chem. 1996; 271: 28002-28005.

48. Jimenez EC, Watkins M, Juszczak LJ, Cruz LJ, Olivera BM. Contryphans from Conus textile venom ducts. Toxicon. 2001; 39: 803-808, Doi 10.1016/S0041-0101(00)00210-5.

49. Amiche M, Delfour A, Morgat JL, Roy J, Houvet J, Nicolas P. Specific opioid binding sites for dermorphin in rat brain. A radioreceptor assay using the tritiated hormone as primary ligand. Biochem. Biophys. Res. Commun. 1987; 148: 1432-1439.

50. Amiche M, Delfour A, Nicolas P. Structural requirements for dermorphin opioid receptor binding. Int. J. Pept. Protein Res. 1988; 32: 28-34.

51. Mor A, Delfour A, Amiche M, Sagan S, Nicolas P, Grassi J, Pradelles P. Dermorphin and related peptides in rat tissues. Neuropeptides. 1989; 13: 51-57.

52. Amiche M, Sagan S, Mor A, Delfour A, Nicolas P. Dermenkephalin (Tyr-D-Met-Phe-His-LeuMet-Asp- $\mathrm{NH}_{2}$ ): a potent and fully specific agonist for the delta opioid receptor. Mol. Pharmacol. 1989; 35: 774-779.

53. Morishita F, Nakanishi Y, Kaku S, Furukawa Y, Ohta S, Hirata T, Ohtani M, Fujisawa Y, Muneoka Y, Matsushima O. A novel D-amino-acid-containing peptide isolated from Aplysia heart. Biochem. Biophys. Res. Commun. 1997; 240: 354-358.

54. Fujita K MH, Nomoto K, Furukawa Y, Kobayashi M. Structure-activity relations of fulicin, a peptide containing a D-amino acid residue. Peptides.1995; 16: 565-568.

55. Fujisawa Y, Ikeda T, Nomoto K, Yasuda-Kamatani Y, Minakata H, Kenny PT, Kubota I, Muneoka Y. The FMRFamide-related decapeptide of Mytilus contains a D-amino acid residue. Comp. Biochem. Physiol. C. 1992; 102: 91-95.

56. Kamatani $\mathrm{Y}$, Minakata $\mathrm{H}$, Kenny $\mathrm{P}$, Iwashita $\mathrm{T}$, Watanabe K, Funase K, Sun XP, Yongsiri A, Kim KH, Novales-Li P, Novales ET, Kanapi CG, Takeuchi H, Nomoto K. Achatin-I, an endogenous neuroexcitatory tetrapeptide from Achatina fulica Férussac containing a D-amino acid residue. Biochem. Biophys. Res. Commun. 1989; 160: 1015-1020.

57. Heck SD, Kelbaugh PR, Kelly ME, Thadeio PF, Saccomano NA, Stroh JG, Volkmann RA. Disulfide Bond Assignment of $\omega$-Agatoxin-Ivb and $\omega$-Agatoxin-Ivc - Discovery of a D-Serine Residue in $\omega$-Agatoxin-Ivb. J. Am. Chem. Soc. 1994; 116: 10426-10436, Doi 10.1021/Ja00102a009.

58. Soyez D, Van Herp F, Rossier J, Le Caer JP, Tensen CP, Lafont R. Evidence for a conformational polymorphism of invertebrate neurohormones. D-amino acid residue in crustacean hyperglycemic peptides. J. Biol. Chem. 1994; 269: 18295-18298.

59. Keller R, Kegel G, Reichwein B, Sedlmeier D, Soyez D. in Recent Developments in Comparative Endocrinology and Neurobiology (Eds: Roubos EW, Wendelaar Bonga SE, Vaudry H, De Loof A) Shaker, Nijmegen, 1999, pp. 209-212. 
60. Yasuda A, Yasuda Y, Fujita T, Naya Y. Characterization of crustacean hyperglycemic hormone from the crayfish (Procambarus clarkii): Multiplicity of molecular forms by stereoinversion and diverse functions. Gen. Comp. Endocrinol. 1994; 95: 387-398.

61. Serrano L, Blanvillain G, Soyez D, Charmantier G, Grousset E, Aujoulat F, Spanings-Pierrot C. Putative involvement of crustacean hyperglycemic hormone isoforms in the neuroendocrine mediation of osmoregulation in the crayfish Astacus leptodactylus. J. Exp. Biol. 2003; 206: 979988.

62. Ollivaux C, Gallois D, Amiche M, Boscameric M, Soyez D. Molecular and cellular specificity of post-translational aminoacyl isomerization in the crustacean hyperglycaemic hormone family. FEBS J. 2009; 276: 4790-4802, 10.1111/j.1742-4658.2009.07180.x.

63. Ollivaux C, Vinh J, Soyez D, Toullec JY. Crustacean hyperglycemic and vitellogenesisinhibiting hormones in the lobster Homarus gammarus. FEBS J. 2006; 273: 2151-2160, 10.1111/j.1742-4658.2006.05228.x.

64. Soyez D, Van Deijnen JE, Martin M. Isolation and characterization of a vitellogenesisinhibiting factor from sinus glands of the lobster Homarus americanus. J. Exp. Zool. 1987; 244: 479-484.

65. De Plater GM, Martin RL, Milburn PJ. The natriuretic peptide (ovCNP-39) from platypus (Ornithorhynchus anatinus) venom relaxes the isolated rat uterus and promotes oedema and mast cell histamine release. Toxicon. 1998; 36: 847-857.

66. Torres AM, Tsampazi C, Geraghty DP, Bansal PS, Alewood PF, Kuchel PW. D-amino acid residue in a defensin-like peptide from platypus venom: effect on structure and chromatographic properties. Biochem. J. 2005; 391: 215-220, 10.1042/BJ20050900.

67. Broccardo M, Erspamer V, Falconieri Erspamer G, Improta G, Linari G, Melchiorri P, Montecucchi PC. Pharmacological data on dermorphins, a new class of potent opioid peptides from amphibian skin. Br. J. Pharmacol. 1981; 73: 625-631.

68. Bansal PS, Torres AM, Crossett B, Wong KK, Koh JM, Geraghty DP, Vandenberg JI, Kuchel PW. Substrate specificity of platypus venom L- to-D-peptide isomerase. J. Biol. Chem. 2008; 283: 8969-8975, 10.1074/jbc.M709762200.

69. Kuchel PW, Pages G, Naumann C. 'Chiral compartmentation' in metabolism: Enzyme stereo-specificity yielding evolutionary options. FEBS Letters. 2013; 587: 2790-2797.

70. Lebaupain F, Boscameric M, Pilet E, Soyez D, Kamech N. Natural and synthetic chiral isoforms of crustacean hyperglycemic hormone from the crayfish Astacus leptodactylus: hyperglycemic activity and hemolymphatic clearance. Peptides. 2012; 34: 65-73, 10.1016/j.peptides.2012.01.019.

71. Söll D. The accuracy of aminoacylation-ensuring the fidelity of the genetic code. Experientia. 1990; 46: 1089-1096.

72. Morishita F, Furukawa Y, Matsushima O. Molecular cloning of two distinct precursor genes of NdWFamide, a D-tryptophan-containing neuropeptide of the sea hare, Aplysia kurodai. Peptides. 2012; 38: 291-301, 10.1016/j.peptides.2012.08.025.

73. Kiviriko IK, Prockop DJ. Enzymatic hydroxylation of proline and lysine in protocollagen. Proc. Natl. Acad. Sci. USA. 1967; 57.

74. Mor A, Delfour A, Nicolas P. Identification of a D-alanine containing polypeptide precursor for the peptide opioid, Dermorphin. J. Biol. Chem. 1991; 266: 6264-6270.

75. Auvynet C, Seddiki N, Dunia I, Nicolas P, Amiche M, Lacombe C. Post-translational amino acid racemization in the frog skin peptide deltorphin I in the secretion granules of cutaneous serous glands. Eur. J. Cell. Biol. 2006; 85: 25-34.

76. Soyez D, Toullec JY, Ollivaux C, Geraud G. L- to D-amino acid isomerization in a peptide hormone is a late post-translational event occurring in specialized neurosecretory cells. J. Biol. Chem. 2000; 275: 37870-37875, 10.1074/jbc.M007302200.

77. Ollivaux C, Soyez D. Dynamics of biosynthesis and release of crustacean hyperglycemic hormone isoforms in the X-organ-sinus gland complex of the crayfish Orconectes limosus. Eur. J. Biochem. 2000; 267: 5106-5114, ejb1574. 
78. Soyez D, Laverdure AM, Kallen J, Van Herp F. Demonstration of a cell-specific isomerization of invertebrate neuropeptides. Neuroscience. 1998; 82: 935-942, S0306452297002546.

79. Gallois D, Brisorgueil MJ, Conrath M, Mailly P, Soyez D. Posttranslational isomerization of a neuropeptide in crustacean neurosecretory cells studied by ultrastructural immunocytochemistry. Eur. J. Cell. Biol. 2003; 82: 431-440.

80. Shikata Y, Watanabe T, Teramoto T, Inoue A, Kawakami Y, Nishizawa K, Katayama K, Kuwada M. Isolation and characterization of a peptide isomerase from funnel web spider venom. J. Biol. Chem. 1995; 270: 16719-16723.

81. Shikata Y, Ohe I, Mano N, Kuwuda M, Asakawa N. Structural analysis of N-linked carbohydrate chains of funnel web spider (Agenelopsis aperta) venom peptide isomerase. Biosc. Biotechnol. Biochem. 1998; 62: 1211-1215.

82. Murkin AS, Tanner ME. Dehydroalanine based inhibition of a peptide epimerase from spider venom. J. Org. Chem. 2002; 67: 8389-8394.

83. Torres AM, Tsampazi M, Tsampazi C, Kennett EC, Belov K, Geraghty DP, Bansal PS, Alewood PF, Kuchel PW. Mammalian L- to D-amino-acid-residue isomerase from platypus venom. FEBS Lett. 2006; 580: 1587-1591.

84. Torres AM, Tsampazi M, Kennett EC, Belov K, Geraghty DP, Bansal PS, Alewood PF, Kuchel PW. Characterization and isolation of L- to D-amino-acid-residue isomerase from platypus venom. Amino Acids. 2007; 32: 63-68.

85. Koh JMS, Haynes L, Belov K, P.W. K. L- to D-peptide isomerase in male echidna venom. Australian J. Zool. 2010; 58: 284-288.

86. Koh JM, Chow SJ, Crossett B, Kuchel PW. Mammalian peptide isomerase: platypus-type activity is present in mouse heart. Chem. Biodivers. 2010; 7: 1603-1611, 10.1002/cbdv.200900300.

87. Arakawa K, Koh JM, Crossett B, Torres AM, Kuchel PW. Detection of platypus-type L/Dpeptide isomerase activity in aqueous extracts of papaya fruit. Biotechnol. Lett. 2012; 34: 16591665, 10.1007/s10529-012-0941-4.

88. Miele R, Ponti D, Boman HG, Barra D, Simmaco M. Molecular cloning of a bombinin gene from Bombina orientalis: detection of NF-кB and NF-IL6 binding sites in its promoter. FEBS Lett. 1998; 431: 23-28.

89. Harada N, lijima S, Kobayashi K, Yoshida T, Brown WR, Hibi T, Oshima A, Morikawa M. Human IgGFc binding protein (FcyBP) in colonic epithelial cells exhibits mucin-like structure. $J$. Biol. Chem. 1997; 272: 15232-15241.

90. Dooley CT, Chung NN, Wilkes BC, Schiller PW, Bidlack JM, Pasternak GW, Houghten RA. An all D-amino acid opioid peptide with central analgesic activity from a combinatorial library. Science. 1994; 266: 2019-2022.

91. Erspamer V. The opioid peptides of the amphibian skin. Int. J. Dev. Neurosci. 1992; 10: 330.

92. Mignogna G, Simmaco M, Kreil G, Barra D. Antibacterial and haemolytic peptides containing D-alloisoleucine from the skin of Bombina varietaga. EMBO J. 1993; 12: 4829-4832.

93. Cava F, Lam H, de Pedro MA, Waldor MK. Emerging knowledge of regulatory roles of Damino acids in bacteria. Cell. Mol. Llife Sci. 2011; 68: 817-831.

94. Takahashi $\mathrm{O}$, Kobayashi $\mathrm{K}$, Oda $\mathrm{A}$. Computational insight into the mechanism of serine residue racemization. Chem. Biodivers. 2010; 7: 1625-1629.

95. Gallo KA, Knowles JR. Purification, cloning, and cofactor independence of glutamate racemase from Lactobacillus. Biochemistry. 1993; 32: 3981-3990.

96. Liu L, Iwata K, Kita A, Kawarabayasi Y, Yohda M, Miki K. Crystal structure of aspartate racemase from Pyrococcus horikoshii OT3 and its implications for molecular mechanism of PLPindependent racemization. J. Mol. Biol. 2002; 319: 479-489, 10.1016/S0022-2836(02)00296-6.

97. Nakajima N, Tanizawa K, Tanaka H, Soda K. Cloning and expression in Escherichia coli of the glutamate racemase gene from Pediococcus pentosaceus. Agric. Chem. Biol.1986; 50.

98. Gallo KA, Tanner ME, Knowles JR. Mechanism of the reaction catalyzed by glutamate racemase. Biochemistry. 1993; 32: 3991-3997. 
99. Fisher LM, Albery WJ, Knowles JR. Energetics of proline racemase: tracer perturbation experiments using $\left[{ }^{14} \mathrm{C}\right]$ proline that measure the interconversion rate of the two forms of free enzyme. Biochemistry. 1986; 25: 2538-2542.

100. Hwang KY, Cho CS, Kim SS, Sung HC, Yu YG, Cho Y. Structure and mechanism of glutamate racemase from Aquifex pyrophilus. Nat. Struct. Biol. 1999; 6: 422-426, 10.1038/8223.

101. Heck SD, Faraci WS, Kelbauch PR, Saccamo NA, Thadeio PF, Volkmann RA. Posttranslational amino acid epimerization: enzyme-catalyzed isomerization of amino acid residues in peptide chain. Proc. Natl. Acad. Sci. USA. 1996; 93: 4036-4039.

102. Volkmann RA, Heck SD. in D-amino acids in sequences of secreted peptides of multicellular organisms (Ed: Jollès) Birkhäuser Verlag, Basel, Boston, London, 1998, pp 87-108.

103. Gerlt JA, Gassman PG. Understanding the rates of certain enzyme-catalyzed reactions: proton abstraction from carbon acids, acyl-transfer reactions, and displacement reactions of phosphodiesters. Biochemistry.1993; 32: 11943-11952.

104. Cleland WW, Kreevoy MM. Low-barrier hydrogen bonds and enzymic catalysis. Science. 1994; 264: 1887-1890.

105. Jilek A, Mollay C, Lohner K, Kreil G. Substrate specificity of a peptidyl-aminoacyl-L/Disomerase from frog skin. Amino Acids. 2012; 42: 1757-1764, 10.1007/s00726-011-0890-6.

106. Amiche M, Delfour A, Nicolas P. in D-amino acids in sequences of secreted peptides of multicellular organisms (Ed: Jollès) Birkhäuser Verlag, Basel, Boston, London, 1998, pp 57-71.

107. Lazarus LH, Bryant SD, Cooper PS, Salvadori S. What peptides these deltorphins be. Prog. Neurobiol. 1999; 57: 377-420.

108. Negri L, Melchiorri P, Lattanzi R. Pharmacology of amphibian opiate peptides. Peptides. 2000; 21: 1639-1647.

109. Conlon JM, Demandt A, Nielsen PF, Leprince J, Vaudry H, Woodhams DC. The alyteserins: Two families of antimicrobial peptides from the skin secretions of the midwife toad Alytes obstetricans (Alytidae). Peptides. 2009; 30: 1069-1073, Doi 10.1016/J.Peptides.2009.03.004.

110. Halverson T, Basir YJ, Knoop FC, Conlon JM. Purification and characterization of antimicrobial peptides from the skin of the North American green frog Rana clamitans. Peptides. 2000; 21: 469-476.

111. Conlon JM, Kolodziejek J, Nowotny N, Leprince J, Vaudry H, Coquet L, Jouenne T, King JD. Characterization of antimicrobial peptides from the skin secretions of the Malaysian frogs, Odorrana hosii and Hylarana picturata (Anura:Ranidae). Toxicon. 2008; 52: 465-473, 10.1016/j.toxicon.2008.06.017.

112. Castro MS, Ferreira TC, Cilli EM, Crusca E, Jr., Mendes-Giannini MJ, Sebben A, Ricart CA, Sousa MV, Fontes W. Hylin a1, the first cytolytic peptide isolated from the arboreal South American frog Hypsiboas albopunctatus ("spotted treefrog"). Peptides. 2009; 30: 291-296, 10.1016/j.peptides.2008.11.003.

113. Chen H, Wang L, Zeller M, Hornshaw M, Wu Y, Zhou M, Li J, Hang X, Cai J, Chen T, Shaw C. Kassorins: novel innate immune system peptides from skin secretions of the African hyperoliid frogs, Kassina maculata and Kassina senegalensis. Mol. Immunol. 2011; 48: 442-451, 10.1016/j.molimm.2010.09.018.

114. Craig AG, Jimenez EC, Dykert J, Nielsen DB, Gulyas J, Abogadie FC, Porter J, Rivier JE, Cruz LJ, Olivera BM, Mclntosh JM. A novel post-translational modification involving bromination of tryptophan. Identification of the residue, L-6-bromotryptophan, in peptides from Conus imperialis and Conus radiatus venom. J. Biol. Chem. 1997; 272: 4689-4698.

115. Jimenez EC, Craig AG, Watkins M, Hillyard DR, Gray WR, Gulyas J, Rivier JE, Cruz LJ, Olivera BM. Bromocontryphan: post-translational bromination of tryptophan. Biochemistry. 1997; 36: 989-994, 10.1021/bi962840p.

116. Soyez D. in D-Amino Acids: A New Frontier in Amino Acid and Protein Research - Practical methods and protocols (Eds: Bruckner H, Fisher AG, Fujii N, Homma H, Konno R) Nova Sciences Publishers, Hauppauge New York, 2006, pp 431-440.

117. Liechti GW, Kuru E, Hall E, Kalinda A, Brun YV, Vannieuwenhze M, Maurelli. AT. A new metabolic cell-wall labelling method reveals peptidoglycan in Chlamydia trachomatis. Nature. 2013, doi: 10.1038/nature12892. 
118. Noda M, Matoba $Y$, Kumagai T, Sugiyama M. Structural evidence that alanine racemase from a D-cycloserine-producing microorganism exhibits resistance to its own product. J. Biol. Chem. 2004; 279: 46153-46161.

119. Kreil G, Barra D, Simmaco M, Erspamer V, Falconieri Erspamer G, Negri L, Severini C, Corsi $\mathrm{R}$, Melchiorri $\mathrm{P}$. Deltorphin, a novel amphibian skin peptide with high selectivity and affinity for $\partial$ opioid receptors. Eur. J. Biochem. 1989; 162: 123-128.

120. Barra D, Mignogna G, Simmaco M, Pucci P, Severini C, Falconierierspamer G, Negri L, Erspamer V. D-Leu 2 Deltorphin, a 17 Amino Acid Opioid Peptide from the Skin of the Brazilian Hylid Frog, Phyllomedusa burmeisteri. Peptides. 1994; 15: 199-202.

121. Heck SD, Kelbaugh PR, Kelly ME, Thadeio PF, Saccomano NA, Stroh JG, Volkmann RA. Disulfide Bond Assignment of $\omega$-Agatoxin-Ivb and $\omega$-Agatoxin-Ivc - Discovery of a D-Serine Residue in $\omega$-Agatoxin-Ivb. J. Am. Chem. Soc. 1994; 116: 10426-10436, Doi 10.1021/Ja00102a009.

122. Buczek O, Yoshikami D, Bulaj G, Jimenez EC, Olivera BM. Post-translational amino acid isomerization: a functionally important D-amino acid in an excitatory peptide. J. Biol. Chem. 2005; 280: 4247-4253, 10.1074/jbc.M405835200.

123. Buczek O, Yoshikami D, Watkins M, Bulaj G, Jimenez EC, Olivera BM. Characterization of D-amino-acid-containing excitatory conotoxins and redefinition of the l-conotoxin superfamily. FEBS J. 2005; 272: 4178-4188, 10.1111/j.1742-4658.2005.04830.x.

124. Jacobsen R, Jimenez EC, Grilley M, Watkins M, Hillyard D, Cruz LJ, Olivera BM. The contryphans, a D-tryptophan-containing family of Conus peptides: interconversion between conformers. J. Pept. Res. 1998; 51: 173-179.

125. Jacobsen RB, Jimenez EC, De la Cruz RG, Gray WR, Cruz LJ, Olivera BM. A novel Dleucine-containing Conus peptide: diverse conformational dynamics in the contryphan family. $J$. Pept. Res. 1999; 54: 93-99.

126. Dutertre S, Lumsden NG, Alewood PF, Lewis RJ. Isolation and characterisation of conomap-Vt, a D-amino acid containing excitatory peptide from the venom of a vermivorous cone snail. FEBS Lett. 2006; 580: 3860-3866, 10.1016/j.febslet.2006.06.011.

127. Han $Y$, Huang $F$, Jiang $H$, Liu L, Wang Q, Wang Y, Shao X, Chi C, Du W, Wang C. Purification and structural characterization of a D-amino acid-containing conopeptide, conomarphin, from Conus marmoreus. FEBS J. 2008; 275: 1976-1987, 10.1111/j.17424658.2008.06352.x.

128. Pisarewicz K, Mora D, Pflueger FC, Fields GB, Mari F. Polypeptide chains containing D- $\chi$ hydroxyvaline. J. Am. Chem. Soc. 2005; 127: 6207-6215.

129. Torres AM, Menz I, Alewood PF, Bansal P, Lahnstein J, Gallagher CH, Kuchel PW. D-amino acid residue in the C-type natriuretic peptide from the venom of the mammal, Ornithorhynchus anatinus, the Australian platypus. FEBS Lett. 2002; 524: 172-176.

130. Ohta N, Kubota I, Takao T, Shimonishi Y, Yasuda-Kamatani Y, Minakata H, Nomoto K, Muneoka Y, Kobayashi M. Fulicin, a novel neuropeptide containing a D-amino acid residue isolated from the ganglia of Achatina fulica. Biochem. Biophys. Res. Commun. 1991; 178: 486493.

131. Yasuda-Kamatani $Y$, Kobayashi M, Yasuda A, Fujita T, Minakata $H$, Nomoto K, Nakamura $M$, Sakiyama F. A novel D-amino acid-containing peptide, fulyal, coexists with fulicin gene-related peptides in Achatina atria. Peptides.1997; 18: 347-354.

132. Iwakoshi $E$, Hisada $M$, Minakata $H$. Cardioactive peptides isolated from the brain of a Japanese octopus, Octopus minor. Peptides. 2000; 21: 623-630. 

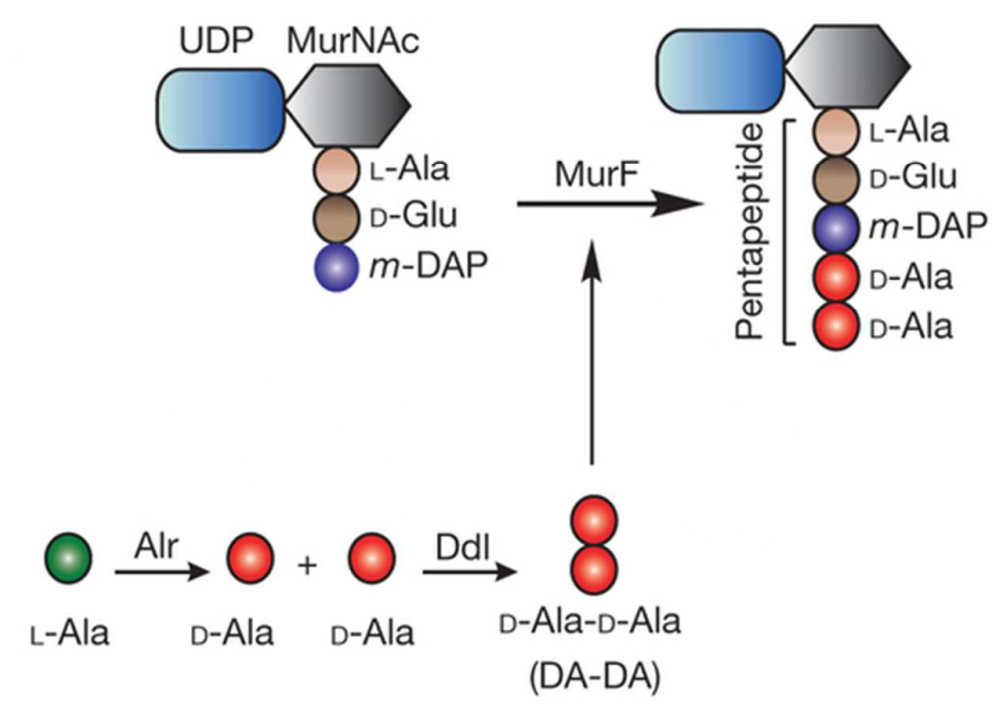

http://mc.manuscriptcentral.com/jpsc 


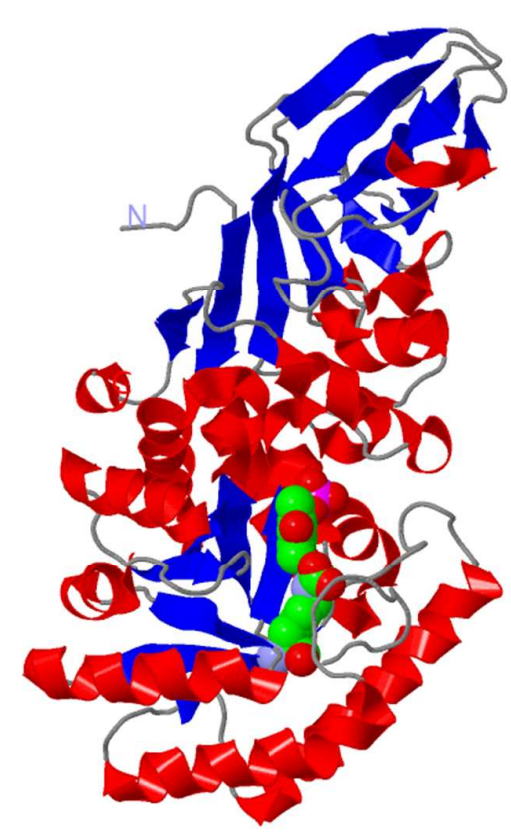

http://mc.manuscriptcentral.com/jpsc 
1

2

3

4

6

7

8

10

11

12

13

14

15

16

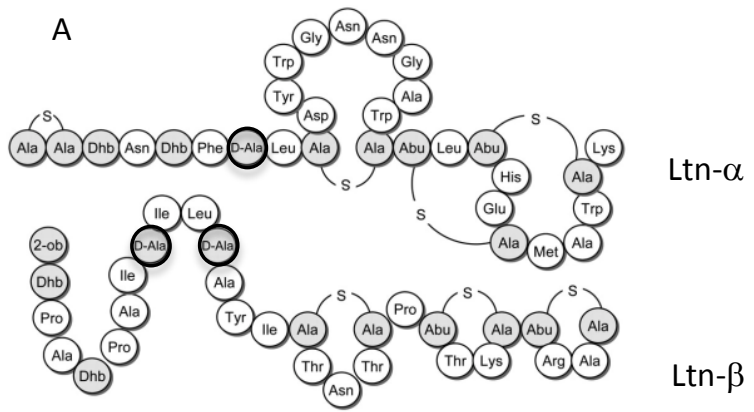

B

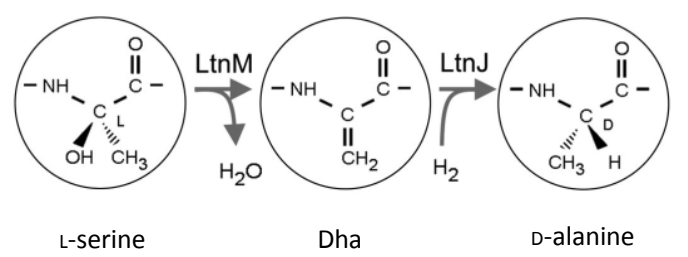

http://mc.manuscriptcentral.com/jpsc 

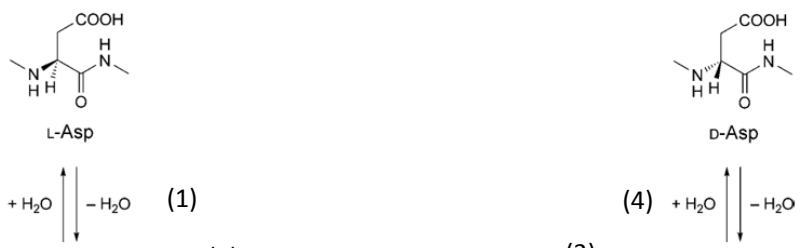

$\left.+\mathrm{H}_{2} \mathrm{O}\right\rfloor-\mathrm{H}_{2} \mathrm{O} \quad(1)$

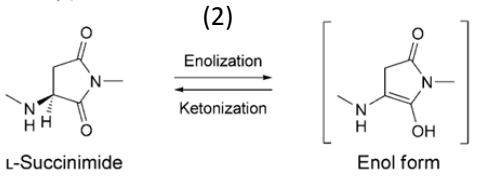

(3)

$-\mathrm{H}_{2} \mathrm{O}||+\mathrm{H}_{2} \mathrm{O}$

(4)
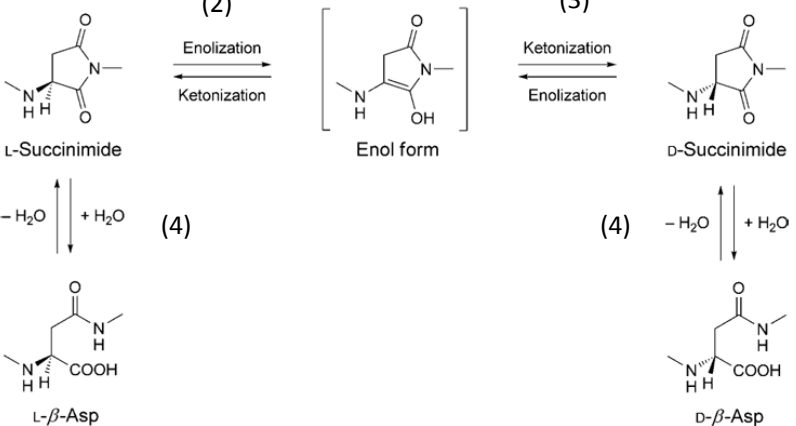

(4) $-\mathrm{H}_{2} \mathrm{O} \mid \downarrow+\mathrm{H}_{2} \mathrm{O}$

L- $\beta$-Asp

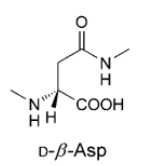



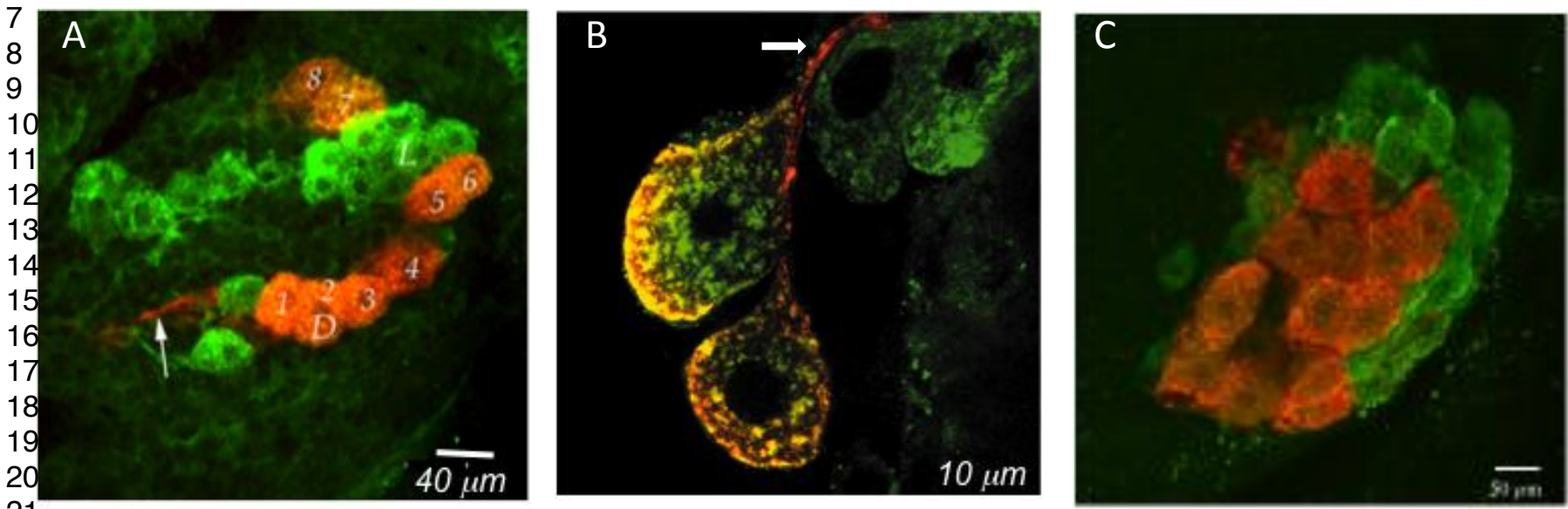

22
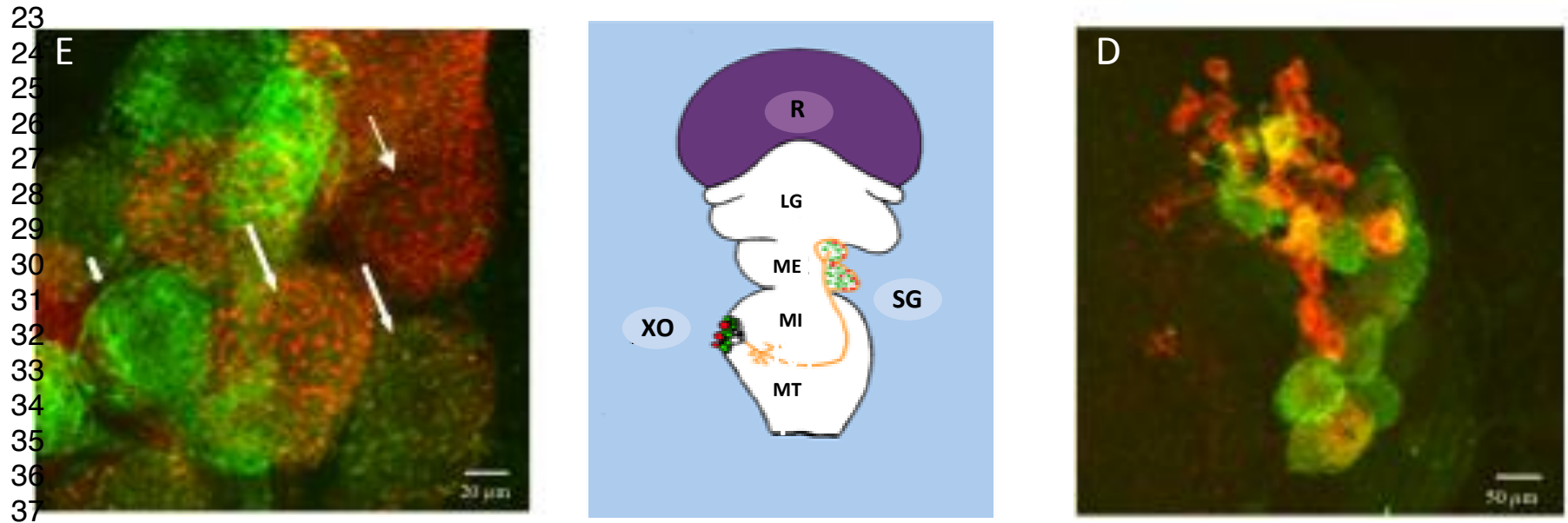

40

41

42

43

44

45

46

47

48

49

50

51

52

53

54 


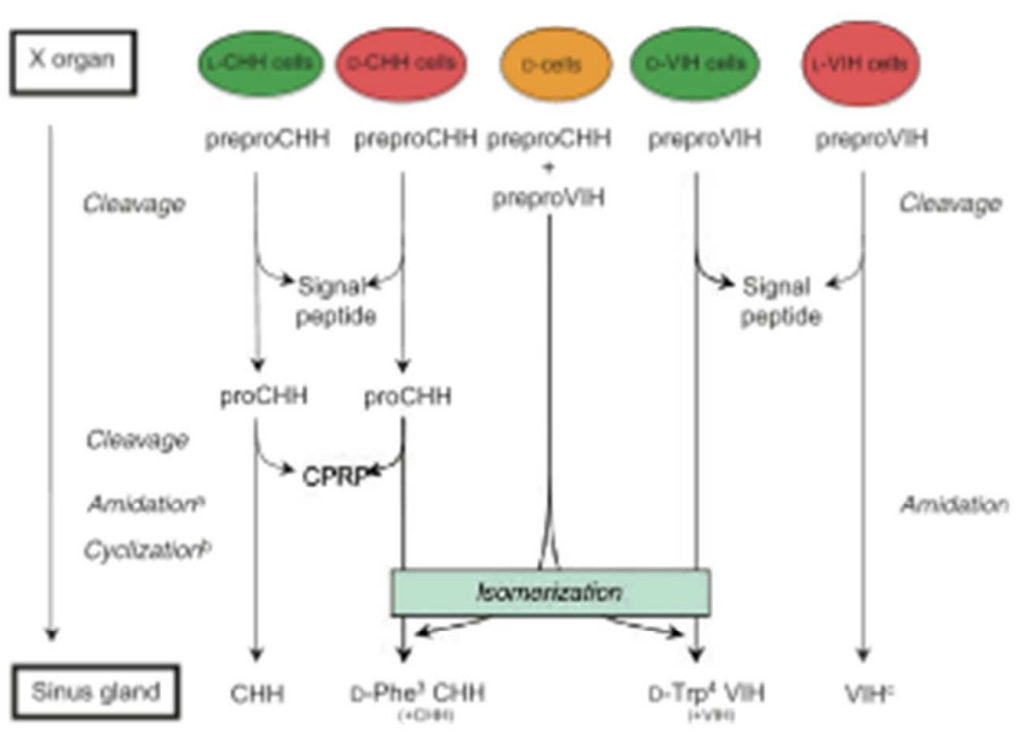

http://mc.manuscriptcentral.com/jpsc 


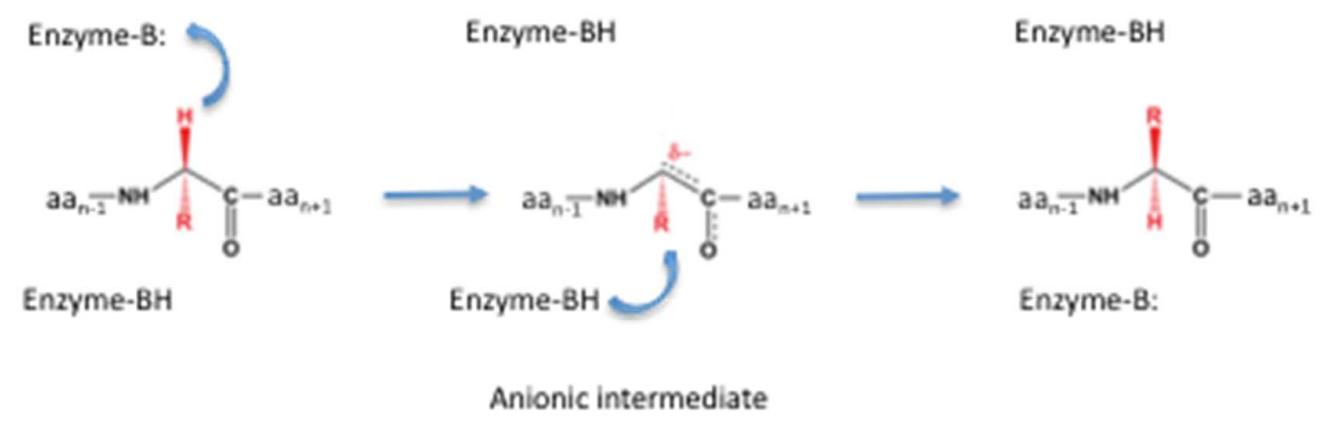

http://mc.manuscriptcentral.com/jpsc 

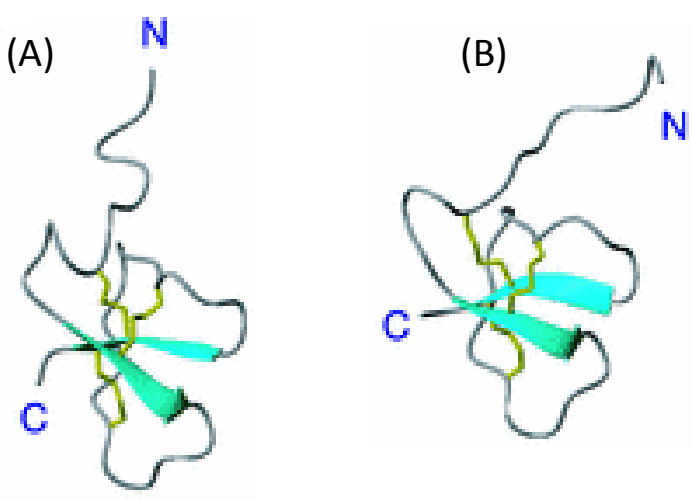

(C)

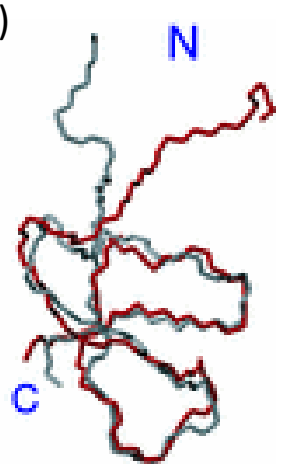




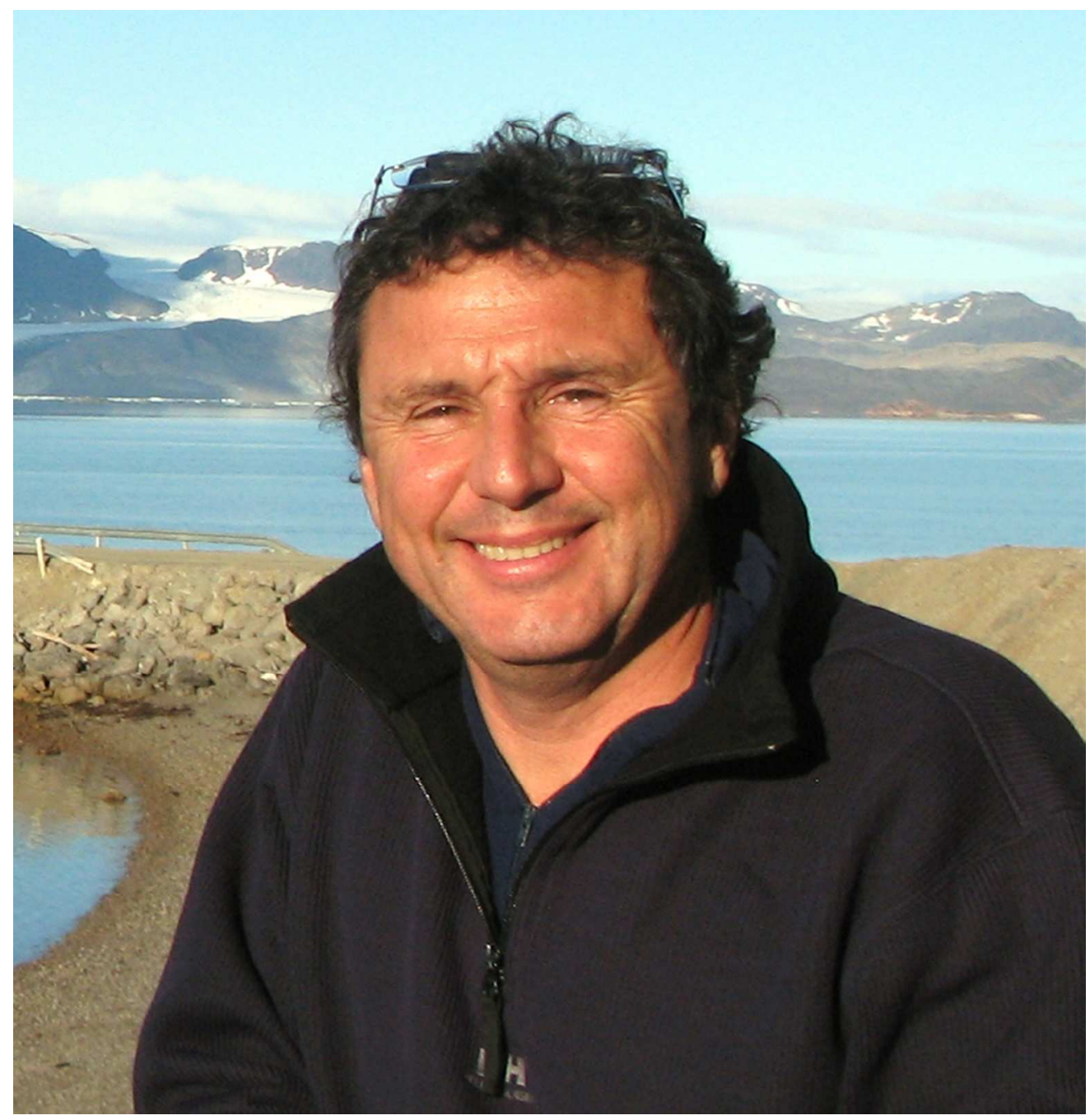

$321 \times 330 \mathrm{~mm}(72 \times 72 \mathrm{DPI})$

http://mc.manuscriptcentral.com/jpsc 


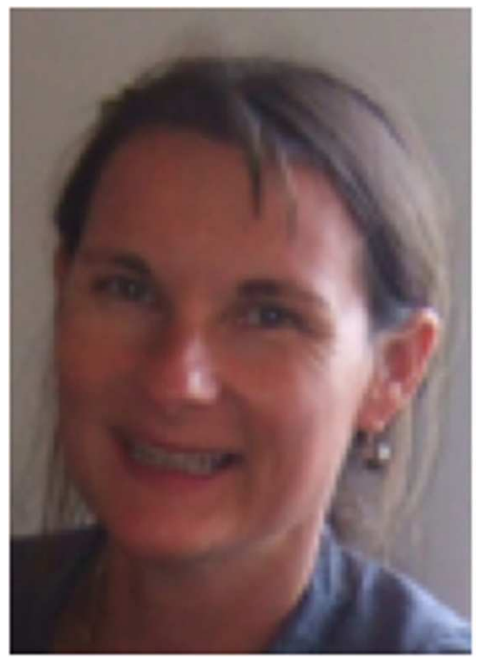

http://mc.manuscriptcentral.com/jpsc 


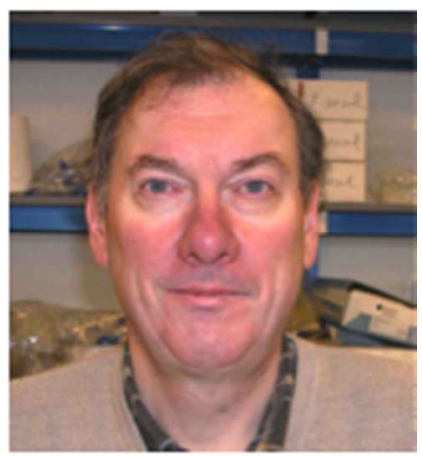

http://mc.manuscriptcentral.com/jpsc 